\title{
The multi-country transmission of sovereign and banking risk: a spatial vector autoregressive approach
}

Article

Accepted Version

Zhu, B. (2018) The multi-country transmission of sovereign and banking risk: a spatial vector autoregressive approach. Spatial Economic Analysis, 13 (4). pp. 422-441. ISSN 17421780 doi: https://doi.org/10.1080/17421772.2018.1473890 Available at http://centaur.reading.ac.uk/76998/

It is advisable to refer to the publisher's version if you intend to cite from the work. See Guidance on citing.

To link to this article DOI: http://dx.doi.org/10.1080/17421772.2018.1473890

Publisher: Taylor \& Francis

All outputs in CentAUR are protected by Intellectual Property Rights law, including copyright law. Copyright and IPR is retained by the creators or other copyright holders. Terms and conditions for use of this material are defined in the End User Agreement. 
CentAUR

Central Archive at the University of Reading

Reading's research outputs online 
The Multi-Country Transmission of Sovereign and Banking Risk: A Spatial Vector Autoregressive Approach

\begin{abstract}
This paper develops a spatial vector autoregressive (SpVAR) model to investigate the transmission of sovereign, banking, and corporate default risks among eleven Eurozone countries for the January 2008-December 2013 period. The results show that a significant proportion of default risk variation is explained by foreign shocks. However, the cross-border sovereign-bank nexus is statistically significant, but economically moderate. Among the three sectors, shocks to the banking sector play the most critical role. On average, for the eleven countries, a foreign banking shock can explain $7 \%, 23 \%$, and $18 \%$ of the forecast error variance of changes in sovereign, banking, and corporate credit default swap (CDS) spreads, respectively.
\end{abstract}

Keywords: Sovereign CDS spreads, Banking CDS spreads, Corporate CDS spreads, Cross-Border Spillover, Spatial Vector Autoregressive Model.

JEL Classifications: C31, C33, F3 


\section{Introduction}

The recent European sovereign debt crisis in the euro area has highlighted the spillover effects of financial and sovereign credit risk. When Greece and Ireland faced increasing doubts about their ability to resolve their debt situation, tensions escalated. This in turn affected Spain and Italy, and ultimately threatened the very existence of the Euro (Erce, 2014). The multi-country transmission of financial markets has therefore received a great deal of attention from both researchers and policy makers.

This paper employs a spatial approach to investigate the cross-border spillovers of sovereign, banking, and non-financial corporate risks. The spatial econometric technique structures the interdependencies between observations at different locations (Asgharian, Hess, \& Liu, 2013; Elhorst, 2014). This approach has been increasingly used in financial studies to quantify the co-movements of international asset markets (Fernandez-Aviles, Montero, \& Orlov, 2012; Asgharian, Hess, \& Liu, 2013; Milcheva \& Zhu, 2015) and the systemic risk in financial institutions (Blasques, Koopman, Lucas, \& Schaumburg, 2014; Eder \& Keiler, 2015; Tonzer, 2015). Most previous studies only measure the cross-border transmission within one sector. However, an interdependence between the default risk of sovereigns, banks and corporates, ${ }^{1}$ referred as the 'sovereign-bank-corporate feedback loop' (Gray, Gross, Paredes, \& Sydow, 2013; Acharya, Drechsler, \& Schnabl, 2014; Alter \& Beyer, 2014; Billio et al., 2014), also exists. Focusing on the spillovers within one sector may thus not be sufficient to capture the risk of collapse of an entire financial system.

This paper extends the spatial model into a multi-variate level - a spatial vector autoregressive (SpVAR) model - to investigate the cross-border 'sovereign-bank-corporate feedback loop'.2 As a combination of a spatial model and panel VAR model, a SpVAR model 
can explicitly measure the contemporaneous dependencies in variables among locations and sectors (see, e.g., Gamerman \& Moreira, 2004; Kelejian \& Prucha, 2004; Beenstock \& Felsenstein, 2007; Holly, Pesaran, \& Yamagata, 2011).

This paper differs from the previous literature in two ways. Firstly, most of the previous literature models the cross-sector and cross-border spillovers of sovereign, banking, and corporate risks using multivariate time series models - in particular, the global vector autoregressive model (GVAR). ${ }^{3,4}$ The estimation for GVAR is on a country-by-country basis, ignoring the endogeneity of foreign variables. This approach is based on the argument that with the increase in the number of countries $(\mathrm{N} \rightarrow \infty)$, the foreign variable becomes 'weakly exogenous'. However, the assumption of 'exogenous foreign variables' is quite restrictive. The concerns about this assumption are discussed in Beenstock \& Felsenstein (2007) and Mutl (2009). SpVAR therefore employs a spatial econometric estimator, which is less restrictive. ${ }^{5}$ Because of the 'weak exogeneity' assumption, the contemporaneous domestic relationship (e.g., between banking and sovereign CDS spreads within each country) is normally excluded in the GVAR modelling. Ignoring the contemporaneous domestic relationship may, however, result in bias in the estimated dependence coefficient. The SpVAR model includes this relationship.

SpVAR is, however, less flexible than the GVAR model. Estimating country by country using ordinary least squares (OLS) in the GVAR model allows for heterogeneous slopes. In SpVAR, as the spatial dependence parameter needs to be estimated using the entire system, the spatial dependence parameter is therefore normally set to be the same for all countries. The complexity in the estimation also restricts the SpVAR from being extended to include the error correction term (ECM). In other words, the SpVAR model in this paper ignores the 
long-term relationship at the level of endogenous variables, which may underestimate the transmission of credit risks in the long run. ${ }^{6}$ Although ignoring the ECM may be suboptimal, it will not seriously affect the conclusion of this paper. The lack of any long-term impact of credit risk is also confirmed by the previous literature. The reason could be that the transmission of the credit risk is boosted in the short term during the crisis period. For example, based on a GVAR model, Chen et al. (2010) find that significant impact of U.S. default risk shocks on the default risk of Chinese, Brazil, and German corporates and banks only lasts for four months after the shock. The results of Gray, Gross, Paredes, \& Sydow (2013) also show that a significant response of sovereign credit spreads, banking system credit risk and corporate sector credit risk occurs only within six months after the shock.

Secondly, this paper also uses several linkages to proxy for cross-country and cross-sector interconnectedness. For instance, the cross-border banking interconnectedness is based on bank exposures, while cross-border linkages among firms are based on trade flows. Most of the previous literature considers only one type of linkage. Eickmeier \& $\mathrm{Ng}$ (2015) show that a combination of trade and financial weights can yield higher predictive accuracy than a model using only trade weights. Gross (2017) also concludes that weights based on trade flows alone are insufficient for the identification of linkages between countries. This paper therefore considers several linkages, and conducts a set of robustness checks to show the appropriateness of the selected weights.

By investigating the default risk among eleven Eurozone countries for the January 2008December 2013 period, this paper finds that cross-border spillovers are not only statistically significant, but also economically relevant. For the eleven Eurozone countries, on average, foreign sovereign, banking, and corporate shocks account for a total of $29 \%$ of the forecast 
error variance of changes in sovereign CDS spreads, $27 \%$ of the variance in changes in banking CDS spreads, and 38\% of that in corporate CDS spreads. However, the cross-border inter-sector transmission is less sizable than the intra-sector spillover. The cross-border sovereign-bank nexus is economically moderate. Among the three sectors, a shock to the banking system yields the most serious impact. On average, a foreign banking shock can explain up to $7 \%, 23 \%$, and $18 \%$ of the forecast error variance of changes in the sovereign, banking, and corporate CDS spreads, respectively.

The remainder of this paper is organized as follows. Section 2 provides the econometric setting, and Section 3 introduces the data. The empirical results are presented in Section 4, and Section 5 concludes.

\section{Econometric modelling}

\subsection{SpVAR model}

A SpVAR model can explain the 'time-space dynamics' in default risk variations in one sector at one location by means of those in other sectors at other locations. The SpVAR model can be defined (Gamerman \& Moreira, 2004; Kelejian \& Prucha, 2004; Beenstock \& Felsenstein, 2007) as:

$$
\begin{aligned}
& y_{j, t}=\sum_{p=0}^{P} \sum_{k=1}^{K} \rho_{j, k, p} W_{t-p}^{j, k} y_{k, t-p}+\sum_{k=1, k \neq j}^{K} \gamma_{j, k} y_{k, t}+\sum_{q=1}^{Q} \sum_{k=1}^{K} \varphi_{j, k, q} y_{k, t-q}+ \\
& \sum_{S=1}^{S} X_{t-s} \beta_{j, s}+D_{N} \alpha_{j}+e_{j, t},
\end{aligned}
$$

with $j, k=1, \ldots, K$ and $t=1, \ldots, T . y_{j, t}$ stands for an $N \times 1$ vector of the $j^{\text {th }}$ endogenous variable in period $t . N$ is the total number of countries, $K$ is the number of endogenous variables, and $T$ 
is the total period. This paper considers a system with three dependent variables $(K=3)$ : $y_{1, t}$ refers to the log-differences of sovereign CDS spreads, $y_{2, t}$ for the log-differences of banking CDS spreads, and $y_{3, t}$ for log-differences of corporate CDS spreads.

$W_{t-p}^{j, k}$ is an $N \times N$ matrix for the spatial structure between the $N$ countries from variable $k$ to variable $j$ at period $t-p^{7}$. It is a standardized non-stochastic matrix with zero diagonal terms. Each off-diagonal term in $W_{t}^{j, k}$ captures the dependence between a pair of countries. When constructing the weight matrix, time-varying weights are employed, considering that the factor that shifts in the spatial weights may have implications for the estimated coefficients. $W_{t}^{j, k} y_{k, t}$ captures the impact of the $k^{\text {th }}$ foreign variable averaged across countries on the $j^{\text {th }}$ variable. $\rho_{j, k, p}$ is the coefficient for the cross-border dependence of variable $j$ on variable $k$. Based on $\mathrm{BIC}$ criteria, $P$ is set as 0 , which means that only contemporaneous spatial dependence variables are included.

$\gamma_{j, k}$ measures the contemporaneous dependence of the $j^{\text {th }}$ variable on the $k^{\text {th }}$ variable in the same country in terms of the default risk. It should be noted that although each weight matrix $\left(W_{t}^{j, k}\right)$ has a zero diagonal element, the relationship between $y_{j}$ and $y_{k}$ in the same country is not zero. The impact of domestic cross-sector variable is measured separately by a unitweighted contemporaneous variable $\left(\sum_{k=1, k \neq j}^{K} \gamma_{j, k} y_{k, t}\right) . \varphi_{j, k}$ is for the lagged dependence of the $j^{\text {th }}$ variable on the $k^{\text {th }}$ variable within the same country. Q is set as 1 based on BIC criteria. $X_{t-s}$ are control variables for regional risks (presented in Section 3). S is set as 1 based on BIC criteria. $\beta_{j, S}$ is the corresponding coefficient vector for the $j^{\text {th }}$ equation. $D_{N}$ includes a country-specific intercept, which captures the remaining time-invariant individual market characteristics, such as financial market development. Lastly, $e_{j, t}$ is an $N \times 1$ vector of 
disturbances at period t. $e_{t} \sim N\left(0, \Sigma_{K} \otimes I_{N}\right)$, and $\Sigma_{K}$ is the variance-covariance matrix for the $K$ equations in the system.

The SpVAR model is estimated by means of a Bayesian estimator for multivariate spatial regression models (LeSage, 1997; Gamerman \& Moreira, 2004; LeSage \& Parent, 2007). The detailed priors and posteriors are in Appendix 1.

\subsection{Spatial weight matrix}

$W_{t}^{j, k}$ should be observed (Kelejian \& Prucha, 1998; Kapoor, Kelejian, \& Prucha, 2007). The spatial weight matrix is specified ad hoc. Trade integration has been prominently put forward as a proxy for the cross-border interconnectedness of markets (see, e.g., Pesaran \& Shin, 1998; Dees, Di Mauro, Pesaran, \& Smith, 2007; Beine, Cosma, \& Vermeulen, 2010; Wälti, 2011; Asgharian, Hess, \& Liu, 2013; Alter \& Beyer, 2014; Gross, 2017). The connections between domestic and foreign firms, as well as between domestic sovereign and foreign firms, are defined based on countries' bilateral trade flows.

Financial integration, such as bilateral bank claim exposures, is another important conduit for the transfer of capital across countries (Bruno \& Shin, 2014; Cetorelli \& Goldberg, 2011; Lane \& McQuade, 2014; McGuire \& Tarashev, 2007). On the asset side, an increase in foreign bank asset exposures is associated with higher credit risk. For instance, when the borrower faces a liquidity problem, the credit risk of the lender increases. The lender may have to respond to that by reducing its balance sheet and decreasing both foreign and domestic credit supply. On the liability side, it should be noted that banks not only lend to foreign borrowers, they also rely heavily on funding from abroad, especially from other banks. As a result, there is a funding risk. The increase in funding risk for banks can also 
increase the funding costs of borrowers. Thus, the banking systems of two countries can be connected via bilateral bank claim exposures.

As for the cross-border interconnectedness between sovereigns (see Table 1), I consider both financial and trade exposure. On the one hand, there is a two-way relation between fiscal and financial stress due to the exposure of banking to both domestic and foreign public debt as well as the explicit and implicit guarantee provided by government. On the other hand, the fiscal position can also be affected by cyclical economic co-movements that are linked by cross-border import and export activities. Both financial and trade weights have been widely used in the previous literature to investigate the spillover of sovereign credit risk (see e.g., Angelini, Farina \& Valentini 2016; Bettendorf, 2016; Bernd \& Khan, 2017). A combination of financial and trade weights has also been used by Chudik \& Fratzscher (2011) to link the financial variables across countries during the 2007-09 financial crisis.

$<<$ Table 1 about here $>>$

Following Asgharian, Hess, \& Liu (2013), the importance of country $l$ to country $h$ is calculated by taking the trade between countries as a proportion of the total trade of country $l$ and $h$ with all other countries:

$F_{h, l, t}^{T}=\frac{\text { Export }_{h, l, t-1}+\text { Export }_{l, h, t-1}}{\sum_{h} \text { Export }_{h, l, t-1}+\sum_{l} \text { Export }_{l, h, t-1}}$,

where $\operatorname{Export}_{h, l, t-1}$ stands for the amount of exports from country $h$ to country $l$ one month before period $t .^{8}$ As past exports would not be affected by credit risk in the future period, the weights based on previous trade flows could be regarded as exogenous to changes in CDS spreads in the current period. In this way, the weight could be regarded as exogenously defined. $F_{h, l, t}^{T}$ measures the importance of country $l$ to country $h$ in terms of trade integration, 
and $h, l=1, \ldots, N$.

In a similar way, the weight based on bank exposures is defined as:

$F_{h, l, t}^{B}=\frac{\text { Claim }_{h, l, t-1}+\text { Claim }_{l, h, t-1}}{\sum_{h} \text { Claim }_{h, l, t-1}+\sum_{l} \operatorname{Claim}_{l, h, t-1}}$,

where Claim $_{h, l, t-1}$ stands for the stock of bank claims from country $h$ to country $l$ one month before $t . F_{h, l, t}^{B}$ measures the importance of country $l$ to country $h$ in terms of bank integration, and $h, l=1, \ldots, N$.

The weight matrix defined by Equations (2) or (3) is then row-standardized to be the corresponding $W_{t}^{j, k}$, so that for each $h, \sum_{h, t} w_{h, l, t}^{j, k}=1$.

\section{Data}

The country sample includes eleven EMU countries: Austria, Belgium, Finland, France, Germany, Greece, Ireland, Italy, the Netherlands, Portugal, and Spain. The estimation period ranges from January 2008 through December 2013. The endogenous variables include the log-differenced CDS spreads ${ }^{9}$ of sovereigns, banks, and non-financial private corporates. The CDS data for each country come from Thomson Reuters Datastream. Aggregate indices of banking and non-financial private corporate CDS spreads for each country are calculated as the capitalization weighted CDS spreads of individual banks or firms. As shown in Figure 1, 2008-2013 period was unstable. Since the first half of 2010, sovereign debt markets in some countries in the Euro area came under unprecedented stress. These tensions peaked in 2011, when investors started large-scale sell-offs of risky assets. The European public authorities announced a number of measures to reduce distress in the financial markets, and the markets gradually calmed down. 
$<<$ Figure 1 about here $>>$

Table 2 reports the summary statistics. Sovereign CDS spreads exhibit the highest average growth rates and deviations among the three kinds of CDS spreads, while corporate CDS spreads show the lowest growth rates and variations. The results for unit root tests indicate that after the log-difference, CDS spreads are stationary.

The inter- and intra-sector correlation coefficient of the growth rate of the CDS spreads between each pair of countries is calculated. Table 2 reports the average correlation coefficients. The average cross-border correlations within each sector all exceed $50 \%$. The cross-border correlations between each pair of sectors are also positive. However, they are smaller than the correlations within the sector. For example, the average correlation coefficient between the change in domestic banking and foreign sovereign CDS spreads is $32 \%$, implying a cross-border 'sovereign-bank feedback loop'.

$<<$ Table 2 about here $>>$

The control variables include the log-differenced Euro Stoxx 50 month-on-month index, the log-differenced VIX index, the Euribor-Eonia spread, the Eonia-German T-bill spread and the change in the Euro-US dollar exchange rate. The control variables also include a list of bad news from Zoli (2013). Data for the trade matrix comes from the Trade Statistics of the OECD. Bilateral FDI flows are taken from the Foreign Direct Investment Statistics of the OECD. Bank balance-sheet exposure is measured by bank claims from the consolidated bank statistics of the BIS, using Table 9B. The consolidated statistics are based on the country of 
origin of the reporting bank and not on its location. This means that the claims from a bank's subsidiary are counted as claims by the country which the bank is from. The exposure is based on the total stock outstanding to all sectors. The detailed definitions and data sources are in Appendix 2.

\section{Results}

\subsection{SpVAR estimation results}

Table 3 shows the SpVAR estimation results. Since insignificant parameters may lose a degree of freedom, restricted SpVAR is applied here, in which all insignificant parameters are excluded. Compared with the goodness of fit of the conventional restricted panel VAR model without spatial consideration, the SpVAR model can significantly improve the model's fit,

with a much higher adjusted R-squared and lower BIC. ${ }^{10}$ The Lagrange Multiplier (LM) test for spatial dependence in error terms (Anselin, 1988) shows that the null hypothesis of 'spatially uncorrelated error terms' cannot be rejected for the SpVAR model. The LM test for temporal autocorrelation (Baltagi \& Li, 1991) does not show significant temporal dependence in the innovations.

The intra-sector contemporaneous spatial coefficients $\left(\rho_{1,1}, \rho_{2,2}\right.$ and $\left.\rho_{3,3}\right)$ are significant at the $5 \%$ level, and all exceed 0.5 . A 1 -percentage point increase in the change of foreign sovereign CDS spreads is associated with an immediate 0.613 -percentage point increase in the change in domestic sovereign CDS spreads. The intensity of the contemporaneous spatial autocorrelation of the banking CDS spread growth is 0.629 , and it is also 0.629 for the change of corporate CDS spreads. 
In addition, the results show significant cross-border spillovers from banks to corporates $\left(\rho_{3,2}=0.212\right)$. An average of 1 -percentage point increase in the change in banking CDS spreads in foreign countries is associated with an immediate 0.212 -percentage point increase in the change in domestic corporate CDS spreads. Table 3 also shows a significant dependence of domestic banks on their sovereign $\left(\gamma_{2,1}=0.081\right.$ and $\left.\varphi_{2,1}=0.049\right)$, which can be caused by implicit and explicit guarantees and the holdings of government debts. The coefficient for the contemporaneous dependence of sovereign on domestic banks is also significant $\left(\gamma_{1,2}=0.086\right)$. The finding confirms a bilateral 'sovereign-bank feedback loop' in the domestic market. The default risk of corporates also significantly affects the default risk of the sovereign $\left(\gamma_{1,3}=0.201\right)$.

$<<$ Table 3 about here $>>$

\subsection{Impulse response and variance decomposition}

In this paper, the magnitude of spillovers in the system is measure by comparing the response to a 1-standard deviation domestic shock and a 1-standard deviation foreign shock. In a SpVAR model, the impulse responses refer to the effects of shocks that occur in a specific region to: (1) The shocked variable in the country where the shock occurred; (2) Other variables in the country where the shock occurred; (3) The shocked variables in other countries; (4) Other variables in other countries. Based on the shock's origination, the forecast error variance is decomposed into six parts. A domestic shock refers to a shock that originates in the home country; a foreign shock is calculated as the weighted individual shocks to the other ten countries (Dees et al., 2007). A foreign shock to the sovereign of a country is weighted according to the total bank and trade exposures of the other ten countries to this country in period $t$-1. A foreign shock to the banking sector of a country is weighted by 
the bank exposures of the other ten countries to this country. A foreign shock to corporates is weighted by the trade flows to this country. ${ }^{11}$ For example, the forecast error variance of changes in Austrian sovereign CDS spreads can be decomposed into that caused by Austrian sovereign shock, the foreign sovereign shock, Austrian banking shock, the foreign banking shock, Austrian corporate shock, and the foreign corporate shock. The share of the forecast error variance of changes in sovereign, banking, and corporate CDS spreads triggered by the six types of shocks for the eleven countries is reported. Because the impulse response and decomposition are based on restricted SpVAR, only significant parameters are used in the impulse response and variance decomposition. The decomposition is therefore based on statistically significant responses. The percentage of explained variance is reported in Table 4. The absolute level of the forecast variance explained by each shock is shown in round brackets. $^{12}$

In addition to statistical significance, economic significance is also considered. Economic significance is measured by comparing the response to each shock based on selected weights and randomly generated weights. There are two steps. Firstly, the SpVAR is estimated using 200 randomly generated weight matrices as:

$y_{j, t}=\sum_{k=1}^{K} \rho_{j, k, p} W_{t}^{\text {random }, j, k} y_{k, t}+\sum_{k=1, k \neq j}^{K} \gamma_{j, k} y_{k, t}+\sum_{k=1}^{K} \varphi_{j, k} y_{k, t-1}+X_{t-1} \beta_{j}+D_{N} \alpha_{j}+$

$e_{j, t}$.

Secondly, the variance decomposition is performed by using the results of the 200 times of SpVAR. The $95^{\text {th }}$ and $5^{\text {th }}$ percentile of the simulated error variance are the upper and lower bounds of the $90 \%$ confidence interval for economic significance. They are reported in square brackets in Table 4.

For space purposes, Table 4 only reports the average decomposition results of the eleven 
countries. ${ }^{13}$ The results confirm significant foreign impacts on domestic markets. On average, approximately $62 \%$ of the forecast error variance of changes in sovereign CDS spreads is attributable to domestic sovereign shock. Foreign shocks explain up to $32 \%$ of sovereign CDS variations, with $20 \%$ attributable to foreign sovereign shock, $7 \%$ attributable to foreign banking shock, and 5\% to foreign corporate shock. Approximately $69 \%$ of the forecast error variance of changes in banking CDS spreads is attributable to domestic banking shock, and $24 \%$ to foreign banking shock. For changes in corporate CDS spreads, $56 \%$ of its forecast error variance is caused by domestic corporate shock, while $19 \%$ is attributable to foreign corporate shock, $19 \%$ to foreign banking shock, and 2\% to foreign sovereign shock. All these responses are statistically significant, as all insignificant coefficients are restricted to zero in the restricted SpVAR model.

The results also show that the sovereign-bank nexus, in both directions, can yield a statistically significant impact on the transmission of credit risks. However, only the banking shock can yield an economically significant impact on sovereign credit risk. The spillover from sovereign to bank, both in the domestic and foreign market, is economically insignificant, as the error variance of changes in banking CDS spreads triggered by the sovereign shock is below the lower bound of the $90 \%$ confidence interval based on 200 randomly generated matrices. Foreign and domestic banking shocks can explain $10 \%$ of the forecast error variance of changes in sovereign CDS spreads, while foreign and domestic sovereign shocks can only explain $5 \%$ of the error variance in banking CDS spreads. Therefore, banks play a relatively more important role in the sovereign-bank nexus. However, the inter-sector transmission (for example, the transmission from foreign banks to sovereign, or from sovereign to foreign banks) is much weaker than the intra-sector spillover (for example, the transmission from sovereign to sovereign and from banks to banks). 
Among the three sectors, banks play the most critical role in the transmission of shocks. The change in the CDS spreads of banks can significantly affect domestic and foreign sovereign and corporates, and altogether can explain $10 \%$ and $23 \%$ of the forecast error variance of changes in sovereign and corporate CDS spreads, respectively. Foreign banking shock can explain $7 \%, 24 \%$, and $19 \%$ of the forecast error variance of changes in domestic sovereign, banking, and corporate CDS spreads, respectively. The forecast error variance trigged by banking shocks all exceeds the upper bound of the $90 \%$ confidence interval for economic significance.

Concerns may arise about endogeneity among the sovereign, banking, and corporate shocks. For example, the increase in banking CDS spreads may lead to increases in sovereign and corporate CDS spreads. However, because of the nexus among sovereigns, banks, and corporates, the increases in the sovereign and corporate CDS spreads can feed back into the banking sector, resulting in an induced banking shock. Such an endogenous relationship can affect impulse response and variance decomposition.

This paper follows den Haan, Sumner, \& Yamashiro (2007) and attempts to disentangle the responses to a banking shock from an endogenous banking shock induced by changes in sovereign or corporate CDS spreads. As in den Haan, Sumner, \& Yamashiro (2007), this feedback effect is removed by restricting to zero the impulse response function of the banking CDS spreads to the other two variables when estimating the responses of sovereign and corporate CDS spreads to the domestic and foreign banking shocks. In Equation (1), the $\rho_{2,1}$, $\rho_{2,3}, \varphi_{2,1} \varphi_{2,3}, \gamma_{2,1}$, and $\gamma_{2,3}$ are restricted to zero, even when any of them are statistically significant. The covariance between the error terms in the domestic sovereign, banking, and 
corporate sectors is also set to zero. In this way, the response of banking CDS spreads to sovereign and corporate CDS spreads is zero. Similarly, strictly exogenous corporate and sovereign shocks are defined by restricting the response functions of these two variables to be zero in the impulse response estimation.

Panel B of Table 4 shows the percentage of the forecast error variance explained by strictly exogenous foreign shocks. The results are qualitatively robust. The percentage of the explained error variance of changes in sovereign CDS spreads triggered by the foreign sovereign shock drops from $20 \%$ to $18 \%$. The total impact from foreign shocks slightly decreases to $29 \%, 27 \%$, and $38 \%$ for sovereign, banking, and corporate CDS spreads, respectively. A shock to the banking system still plays the most critical role. The foreign banking shock can still explain $7 \%, 23 \%$, and $18 \%$ of the variations in sovereign, banking, and corporate CDS spreads, respectively. The forecast error variance explained by the foreign banking shock remains above the $95^{\text {th }}$ percentile of the variance based on 200 simulated weight matrices.

$<<$ Table 4 about here $>>$

\subsection{Discussions and robustness checks}

The baseline results use aggregate BIS bank claim exposures to all sectors to measure the cross-border linkages between banks, sovereigns, and corporates. From 2011, EBA/ECB/SSM have been publishing stress test datasets about bank claims, with detailed breakdowns of the bank's exposures vis-à-vis different segments, such as: other banks, nonfinancial private sectors, and public sectors. ${ }^{1415}$ This segmented bank data provides a way to more precisely estimate between-sector linkages. ${ }^{16}$ 
The results of structural decomposition with sector specific linkages are reported in Table 5 . Overall, the results are qualitatively robust. However, the proportion of the error variance explained by the foreign banking shock decreases to $4 \%, 13 \%$, and $7 \%$ for sovereign, banking, and corporate CDS spreads, respectively. The results imply that the cross-border interconnectedness between banks and other sectors can be better captured by total financial linkages, rather than by sector-specific linkages. One explanation could be the 'balance sheet' theory (Bruno \& Shin, 2014). When banks face liquidity problems due to the increase in the credit risk of one asset (e.g., the sovereign debt), they will respond to this by decreasing their balance sheet and reducing credit supply, not only to that asset, but to other assets as well. Therefore, the interconnectedness between banks and corporates may also be affected by the holding of sovereign debt between the two countries. Another explanation could be the 'wake-up call' theory (Bekaert, et al., 2014). A crisis in one country is a wake-up call for investors to reassess the regional fundamentals of that country. For example, if a country faces difficulty in resolving its debt situation, when a crisis bursts investors may be aware that those countries with large debt exposures to the country in crisis may also suffer a loss and face liquidity problems. Banks may react to this by decreasing the credit supply to all sectors in those countries.

Further robustness tests include using other measures of linkages between countries. Model 3 in Table 5 substitutes bank claim exposures by bilateral portfolio position as an alternative measure of financial integration. Model 4 substitutes direct foreign investments for bilateral trade flows as an alternative measure of trade integration. Model 5 uses similarity of openness to construct potential links between two countries (i.e., instead of trade and financial linkages, the matrices used in Equation (1) are all defined on the basis of the 
similarity between their financial and trade policies). Model 6 uses the traditional weight matrix - the geographic distance matrix - to measure the closeness between two countries. The definition of the weights are provided in Appendix 6.

The results are also reported in Table 5. When the portfolio position is substituted, the results are qualitatively robust. However, the spillover from foreign banks to corporates drops to $9 \%$. So bilateral bank claims best capture the relationship between banks and other sectors. When foreign direct investment (FDI) is substituted for the trade matrix, results remain quite robust. However, when openness and distance are used as weight matrices, the estimated crossborder dependence reduces significantly. When similarity of openness is used, the spillover from banking CDS shock to corporate CDS change drops to zero. The reason could be that within the same economic unit, the financial integration of Euro countries may go beyond what can be explained by the similarity in their integration policies. As a result, similarity of openness is not a suitable measurement of financial linkages. This finding confirms the conclusion of the previous literature that economic or financial distance may be more appropriate to capture the linkages between countries. Overall, the results show that the selection of weights can affect the estimation of the spillover effect. This confirms the finding of the previous literature that weights do matter (Corrado \& Fingleton, 2012; Gross, 2017). In terms of credit risk spreading, physical exposure is a better measure of the linkages than economic similarity or geographic distance.

$<<$ Table 5 about here $>>$

The second issue concerns spatial validation. Spatial models always assume that the comovement between countries should depend on the strength of their linkages. Under this assumption, weights are constructed based on the strength of the linkages. However, this 
assumption has not been formally tested. In other words, it still needs to be checked whether countries with weaker financial or trade linkages do indeed have a lower degree of comovement than countries with stronger linkages.

Given this concern, a distance decay model is applied here. This model explicitly checks whether important neighbours of a country - i.e., neighbours with larger weights - exhibit stronger dependence with the country than unimportant neighbours - i.e., those with smaller weights. The construction of weights follows Asgharian, Hess, \& Liu (2013). It divides the ten foreign countries into two groups - neighbours and non-neighbours. For a single country, the five countries with the strongest trade exposures to it are denoted as neighbours, and the remaining five as non-neighbours (i.e., those with the weakest trade exposures to that country). Once the neighbours and non-neighbours are identified, two weight matrices are constructed: the neighbouring matrix, which is defined with elements $C_{i, j}^{n b}=C_{i, j}$ if $C_{i, j} \geq$ $\operatorname{median}_{j} C_{i, j}$, and zero otherwise, and the non-neighbouring matrix, which is captured by $C_{i, j}^{n o n \_n b}$, with elements $C_{i, j}^{n o n \_n b}=C_{i, j}$ if $C_{i, j}<\operatorname{median}_{j} C_{i, j}$, and zero otherwise. $C^{n b}$ and $C^{n o n \_n b}$ are then row-standardized, and $W_{t}^{n b, j, k}$ and $W_{t}^{n o n_{n b}, j, k}$ are obtained. These two matrices are added into the regression:

$y_{j, t}=\sum_{k=1}^{3} \rho_{j, k}^{n b} W_{t}^{n b, j, k} y_{k, t}+\sum_{k=1}^{3} \rho_{j, k}^{n o n-n b} W_{t}^{n o n_{n b}, j, k} y_{k, t}+\sum_{k=1, \mathrm{k} \neq \mathrm{j}}^{3} \gamma_{j, k} y_{k, t}+$ $\sum_{k=1}^{3} \varphi_{j, k} y_{k, t-1}++X_{t-1} \beta_{j}+D_{N} \alpha_{j}+e_{j, t}$,

where $\rho_{j, k}^{n b}$ is the spatial coefficient for the weight matrix based on the countries with $50^{\text {th }}$ percentile highest trade and/or banking connectedness, and $\rho_{j, k}^{n o n-n b}$ measures the comovement intensity for the weight matrix based on the rest of the countries with $50^{\text {th }}$ percentile lowest linkages. If the financial and/or economic distance between countries really 
matters, $\rho_{j, k}^{n b}$ should be significantly higher than $\rho_{j, k}^{n o n-n b}$, which would mean that countries with stronger linkages do indeed experience stronger co-movement than countries with weaker linkages.

The results are shown in Table 6. $\rho_{1,1}^{n b}, \rho_{2,2}^{n b}$ and $\rho_{3,3}^{n b}$ are significantly higher than $\rho_{1,1}^{n o n} n b$, $\rho_{2,2}^{n o n \_n b}$ and $\rho_{3,3}^{n o n \_n b}$, respectively. The confidence interval of each pair of coefficients does not overlap. $\rho_{3,2}^{n b}$ is also significantly higher than $\rho_{3,2}^{n o n \_n b}$, confirming that the spillover from foreign banks' credit risk to the domestic corporate is indeed triggered by their financial exposures.

$<<$ Table 6 about here $>>$

The third group of robustness checks are about model specification and estimation. ${ }^{17}$ Firstly, the domestic GDP and credit to GDP ratio are included as additional control variables. The estimated spillover effect remains robust. Secondly, heterogeneous variance across countries is assumed, which implies that $e \sim N\left(0, I_{T} \otimes \Sigma_{N K}\right)$, and $\Sigma_{N K}$ is a $N K \times N K$ matrix. The diagonal element is the variance of shocks at location $i$ in sector $k$. The off-diagonal element shows the non-zero covariance. The prior for $\Sigma_{N K}$ is set as multivariate inverse Wishart form, as $\Sigma_{N K} \sim I W\left(v_{0}, S_{0}\right)$, with $v_{0}$ is set as $N K$, and $v_{0} S_{0}$ is set as (1e-12)NK. The results remain qualitatively robust. Thirdly, instead of using lagged trade and financial exposures in past periods, the initial amount of trade flow and financial exposures in 2008 is used to construct the weights. The results are again robust. Apart from using lagged weights, contemporaneous trade and bank exposure over that year are also used as the weights. The results remain robust. Moreover, the results are also relatively robust with different estimates, including IV using lagged explanatory variables as instruments (Kelejian \& Prucha, 1998) and OLS. 


\section{Conclusion}

This paper focuses on the transmission process of sovereign, banking, and non-financial corporate default risks among eleven Eurozone countries in the period from January 2008 through December 2013. Using a spatial vector autoregressive (SpVAR) model, this paper provides empirical evidence for a 'multi-country sovereign-bank-corporate feedback loop' in the Eurozone.

The empirical results show significant and remarkable spatial dependencies across the eleven countries and the three sectors. On average, $29 \%$ of the forecast error variance of changes in sovereign CDS spreads, $27 \%$ of the forecast error variance of changes in the banking CDS spreads, and $38 \%$ of that in the corporate CDS spreads can be traced back to foreign shocks. However, the results show a statistically significant but economically moderate cross-border 'sovereign-bank' nexus. Foreign and domestic banking shocks can explain $10 \%$ of the variance of changes in sovereign CDS spreads, while foreign and domestic sovereign shocks can only explain $5 \%$ of the error variance of banking CDS change. Moreover, among the three sectors, banks play a critical role in the crisis transmission. On average for the eleven countries, a foreign banking shock can predict up to $7 \%, 23 \%$, and $18 \%$ of variations in CDS spreads in the sovereign, banking, and corporate sectors, respectively.

This work could be extended in several ways. First, the error correction term can be incorporated into the model to allow for both long-term and short-term dynamics. Ignoring the long-term relationship may lead to misspecification of the model. Second, time-varying residual covariance can be used to measure the change in the correlation among sovereign, bank, and corporate CDS spreads. Third, instead of the spreads of CDSs, the interdependency 
analyses could be applied to the estimation of probability of default and expected capital shortfalls for individual banks, which could provide a more straightforward way for banks to monitor and manage their credit risk as transmitted from their counterparties.

\footnotetext{
${ }^{1}$ The corporates in this paper always refer to non-financial private corporates.

${ }^{2}$ This paper follows the spatial econometric literature (Cliff \& Ord, 1973; Kelejian \& Prucha, 1999, 2010; Lee, 2004; Baltagi, Fingleton, \& Pirotte, 2014), and uses known spatial weighting matrices to identify the pattern of
} dependence between cross-sectional and cross-border units.

${ }^{3}$ For example, by means of a global VAR model, Gray, Gross, Parades, \& Sydow (2013) calculate the interdependencies of default risk among banks, sovereigns, and corporates for fifteen European countries and the US. Alter \& Beyer (2014) create a contagion index that measures the intensity of spillovers of sovereign and banking default risk among Eurozone countries. They find that the spillover intensities of Greece, Portugal, and Ireland decreased at the beginning of 2012, which implies that ECB interventions successfully reduced systemic risk. Billio et al. (2014) study the transmission of credit risks of major European, U.S., and Japanese banks using contingent claims analyses and Granger causality analyses. They conclude that banks became important sources of credit risk before and during the 2007-2009 global financial crisis. After 2009, sovereign shock played a more important role. Based on the mixed cross-section GAR model, the pioneer works by Gross and Kok (2013) and Gross, Kok, \& Yochowski (2016) study the propagation of bank capital shocks to the economy.

${ }^{4}$ In addition to the GVAR model, SpVAR also takes the similar form as the IVAR model proposed by Chudik \& Pesaran (2011).

${ }^{5}$ Although SpVAR is less restrictive regarding the assumption of exogenous foreign variables, it is still subject to the assumption that the weight matrix should be exogenously identified. Therefore, this paper uses lagged trade flow and/or bank claim stocks to construct the weights. As trade flow and/or bank exposure in the previous periods is less likely to be affected by the default in the future, it is argued that the weight matrix can be regarded as exogenous to the dependent variables. The estimation of SpVAR with endogenous weights is left for future research.

6 Given the fact that the estimation of SpVECM model under the assumption of 'endogenous foreign variables' is still at a very preliminary stage, extending SpVAR model to SpVECM model is left for future research.

${ }^{7} W$ is typically a square matrix in the spatial econometric literature. However, it should be noted that $W$ in principle does not need to be square in size. Recently developed models, such as the mixed cross-section GVAR 
(Gross \& Kok, 2013; Gross, Kok, \& Yochowski, 2016) and unbalanced spatial panel regression (Baltagi, Bresson, \& Etienne, 2015), for example, do not require a square matrix.

${ }^{8}$ An alternative definition could be the average amount of export from country $h$ to country $l$ over the past twelve months before period $t$ (Eder \& Keiler, 2015); or initial trade in January 2008, before the crisis period. Both definitions provide qualitatively robust results. This indicates that the assumption of 'endogenous weights' is likely to be held. Detailed results are available on request from the author.

${ }^{9} \mathrm{CDS}$ changes are defined as log differences in credit spread, or percentages of bps. The log-difference in spreads can be viewed as the return on buying credit protection and thus reducing credit risk (see e.g., Alter and Schüler, 2012; Alter and Bayer, 2013; Acharya and Steffen, 2015; Gross and Kok, 2013).

${ }^{10}$ A detailed comparison of in-sample predictive accuracy is shown in Appendix 5. Detailed results are available on request from the author.

${ }^{11}$ Dees, Di Mauro, Pesaran, \& Smith (2007) use GDP as the weights for individual shocks. GDP is the average GDP for the eleven countries over the period from 2008 to 2013. The results based on GDP weights are completely robust. Detailed results are available on request from the author.

${ }^{12}$ Appendix 4 illustrates the response of the eleven countries to a shock to Italian sovereign, banking, and corporate CDS as an example. It should be noted that the quick die out of the response might be due to the fact that the long-term relationship has not been integrated in the SpVAR model. When the error correction term is incorporated, the response may last for a longer time. However, this shortage will not fundamentally change the conclusion. The lack of persistence of the response is consistent with previous findings (see. e.g. Chen et al., 2010; Gray, Gross, Parades, \& Sydow, 2013).

${ }^{13}$ Decomposition for each individual country is available on request from the author.

${ }^{14}$ Appendix 6 provides detailed definition.

${ }^{15} \mathrm{EBA} / \mathrm{ECB} / \mathrm{SSM}$ data was only published twice: once in 2011 and again in 2014. So the weights from 2008 to 2011 are based on the data published in 2011; the rest of the weights are based on the data in 2014 .

${ }^{16}$ I gratefully acknowledge an anonymous reviewer for suggesting this approach.

${ }^{17}$ The results are in Appendix 7 and 8. 


\section{References}

Acharya, V., Drechsler, I., \& Schnabl, P. (2014). A Pyrrhic victory? Bank bailouts and sovereign credit risk. Journal of Finance, 69, 2689-2739.

Alter, A., \& Beyer, A. (2014). The dynamics of spillover effects during the European sovereign debt turmoil. Journal of Banking \& Finance, 42, 134-153.

Angelini, E. C, Farina, F. \& Valentini, E. (2016). Contagion across Eurozone's sovereign spreads and the Core-Periphery divide. Empirica. 43(1):197-213.

Anselin, L. (1988). Lagrange multiplier test diagnostics for spatial dependence and spatial heterogeneity. Geographical Analysis, 20, 1-17.

Asgharian, H., Hess, W., \& Liu, L. (2013). A spatial analysis of international stock market linkages. Journal of Banking \& Finance, 37, 4738-4754.

Baltagi, B. H., Bresson, G., \& Etienne, J. M. (2015). Hedonic housing prices in Paris: An unbalanced spatial lag pseudo-panel model with nested random effects. Journal of Applied Econometrics, 30, 509-528.

Baltagi, B. H., Fingleton, B., \& Pirotte, A. (2014). Estimating and forecasting with a dynamic spatial panel data model. Oxford Bulletin of Economics and Statistics, 76, 112-138.

Baltagi, B. H., \& Li, Q. (1991). A joint test for serial correlation and random individual effects. Statistics and Probability Letters, 11, 277-280.

Beenstock, M., \& Felsenstein, D. (2007). Spatial vector autoregressions. Spatial Economic Analysis, 2, 167-196.

Beine, M., Cosma, A., \& Vermeulen, R. (2010). The dark side of global integration: Increasing tail dependence. Journal of Banking \& Finance, 34, 184-192.

Bekaert, G., Ehrmann, M., Fratzscher, M., \& Mehl, A. (2014). The global crisis and equity 
market contagion. The Journal of Finance, 69, 2597-2649.

Bettendorf, T. (2017) Spillover effects of credit default risk in the euro area and the effects on the euro: a GVAR approach. Deutsche Bundesbank Discussion Paper.

Billio, M., Getmansky, M., Gray, D., Lo, A. W., Merton, R. C., \& Pelizzon, L. (2014). Sovereign, bank and insurance credit spread: connectedness and system networks. MIT Working Paper.

Blasques, F., Koopman, S. J., Lucas, A., \& Schaumburg, J. (2014). Spillover dynamics for systemic risk measurement using spatial financial time series models. Tinbergen Institute Discussion Paper, 14/107/III.

Bruno, V., \& Shin, H. S. (2014). Globalization of corporate risk taking. Journal of International Business Studies, 45, 800-820.

Cetorelli, N., \& Goldberg, L. S. (2011). Global banks and international shock transmission: Evidence from the crisis. IMF Economic Review, 59, 41-76.

Chen, Q., Gray, D., N'Diaye, P., Oura, H., \& Tamirisa, N. (2010). International transmission of bank and corporate distress. IMF Working Paper, 10/124.

Chudik, A., \& Fratzscher, M. (2011). Identifying the global transmission of the 2007-2009 financial crisis in a GVAR model. European Economic Review, 55, 325-339.

Chudik, A., \& Pesaran, M. H. (2011). Infinite-dimensional VARs and factor models. Journal of Econometrics, 163, 4-22.

Cliff, A., \& Ord, J. K. (1973). Spatial autocorrelation. Pion, London.

Corrado, L., \& Fingleton, B. (2012). Where is the economics in spatial econometrics? Journal of Regional Science, 52, 210-239.

Dees, S., Di Mauro, F., Pesaran, M. H., \& Smith, L. V. (2007). Exploring the international linkages of the Euro area: A global VAR analysis. Journal of Applied Econometrics, 22, 
1-38.

den Haan, W. J., Sumner, S. W., \& Yamashiro, G. M. (2007). Bank loan portfolios and the monetary transmission mechanism. Journal of Monetary Economics, 54, 904-924.

Eder, A., \& Keiler, S. (2015). CDS spreads and contagion among systemically important financial institutions - A spatial econometric approach. International Journal of Finance \& Economics, 20, 291-309.

Eickmeier, S., \& Ng, T. (2015). How do US credit supply shocks propagate internationally? A GVAR approach. European Economic Review, 74, 128-145.

Elhorst, J. P. (2014). Spatial econometrics: from cross-sectional data to spatial panels. Heidelberg, Springer, New York, Dordrecht, London.

Erce, A. (2014). Cross-border banking, externalities and sovereign distress: Does the Euro need a common banking authority? International Journal of Finance \& Economics, 19, 188-203.

Fernandez-Aviles, G., Montero, J. M., \& Orlov, A. G. (2012). Spatial modeling of stock market comovements. Finance Research Letters, 9, 202-212.

Gamerman, D., \& Moreira, A. R. B. (2004). Multivariate spatial regression models. Journal of Multivariate Analysis, 91, 262-281.

Gray, D. F., Gross, M., Paredes, J., \& Sydow, M. (2013). Modeling banking, sovereign, and macro risk in a CCA global VAR. International Monetary Fund.

Gross, M. (2017). Estimating GVAR weight matrices. ECB Working Paper, 1523.

Gross, M., \& Kok, C. (2013). Measuring contagion potential among sovereigns and banks using a mixed-cross-section GVAR. ECB Working Paper, 1570.

Gross, M., Kok, C., \& Yochowski, D. (2016). The impact of bank capital on economic activity Evidence from a mixed-cross-section GVAR model. ECB Working Paper, 1888.

Holly, S., Pesaran, M. H., \& Yamagata, T. (2011). The spatial and temporal diffusion of house 
prices in the UK. Journal of Urban Economics, 69, 2-23.

Kapoor, M., Kelejian, H. H., \& Prucha, I. R. (2007). Panel data models with spatially correlated error components. Journal of Econometrics, 140, 97-130.

Kelejian, H. H., \& Prucha, I. R. (1998). Generalized spatial two-stage least squares procedure for estimating a spatial autoregressive model with autoregressive disturbances. Journal of Real Estate Finance and Economics, 17, 99-121.

Kelejian, H. H., \& Prucha, I. R. (1999). A generalized moments estimator for the autoregressive parameter in a spatial model. International Economic Review, 40, 509-533.

Kelejian, H. H., \& Prucha, I. R. (2004). Estimation of simultaneous systems of spatially interrelated cross sectional equations. Journal of Econometrics, 118, 27-50.

Kelejian, H. H., \& Prucha, I. R. (2010). Specification and estimation of spatial autoregressive models with autoregressive and heteroskedastic disturbances. Journal of Econometrics, $157,53-67$.

Kempa, B. \& Khan, N. S. (2017). Spillover effects of debt and growth in the euro area: Evidence from a GVAR model. International Review of Economics \& Finance, 49(C), 102-111.

Koop, G., Pesaran, M. H., \& Potter, S. M. (1996). Impulse response analysis in nonlinear multivariate models. Journal of Econometrics, 74, 119-147.

Lane, P. R., \& McQuade, P. (2014). Domestic credit growth and international capital flows. Scandinavian Journal of Economics, 116, 218-252.

Lee, L. F. (2004). Asymptotic distributions of quasi-maximum likelihood estimators for spatial autoregressive models. Econometrica, 72, 1899-1925.

LeSage, J. P. (1997). Bayesian estimation of spatial autoregressive models. International Regional Science Review, 20, 113-129.

LeSage, J. P., \& Parent, O. (2007). Bayesian model averaging for spatial econometric models. 
Geographical Analysis, 39, 241-267.

McGuire, P., \& Tarashev, N. (2007). Global monitoring with the BIS international banking statistics. In Research on global financial stability: The use of BIS International Financial Statistics. Bank for International Settlements.

Milcheva, S., \& Zhu, B. (2015). Bank integration and comovements across housing markets in different countries. Journal of Banking \& Finance. [DOI:10.1016/j.jbankfin.2015.07.002]

Mutl, J. (2009). Consistent estimation of global VAR models. Department of Economics and Finance, Institute for Advanced Studies (IHS), Working Paper.

Pesaran, H. H. (2007). A simple panel unit root test in the presence of cross-section dependence. Journal of Applied Econometrics, 22, 265-312.

Pesaran, H. H., \& Shin, Y. (1998). Generalized impulse response analysis in linear multivariate models. Economics Letters, 58, 17-29.

The Heritage Foundation (2014) The 2014 Index of Economic Freedom, www.heritage.org/index/about. [Accessed 3 June 2015]

Tonzer, L. (2015). Cross-border interbank networks, banking risk and contagion. Journal of Financial Stability, 18, 19-32.

Wälti, S. (2011). Stock market synchronization and monetary integration. Journal of International Money and Finance, 30, 96-110.

Zoli, E. (2013). Italian sovereign spreads: Their determinants and pass-through to bank funding costs and lending conditions. International Monetary Fund. 
Figure 1: Sovereign, banking, and corporate CDS spreads

Sovereign CDS

(right axis is for Greece, left axis is for the rest of the countries)
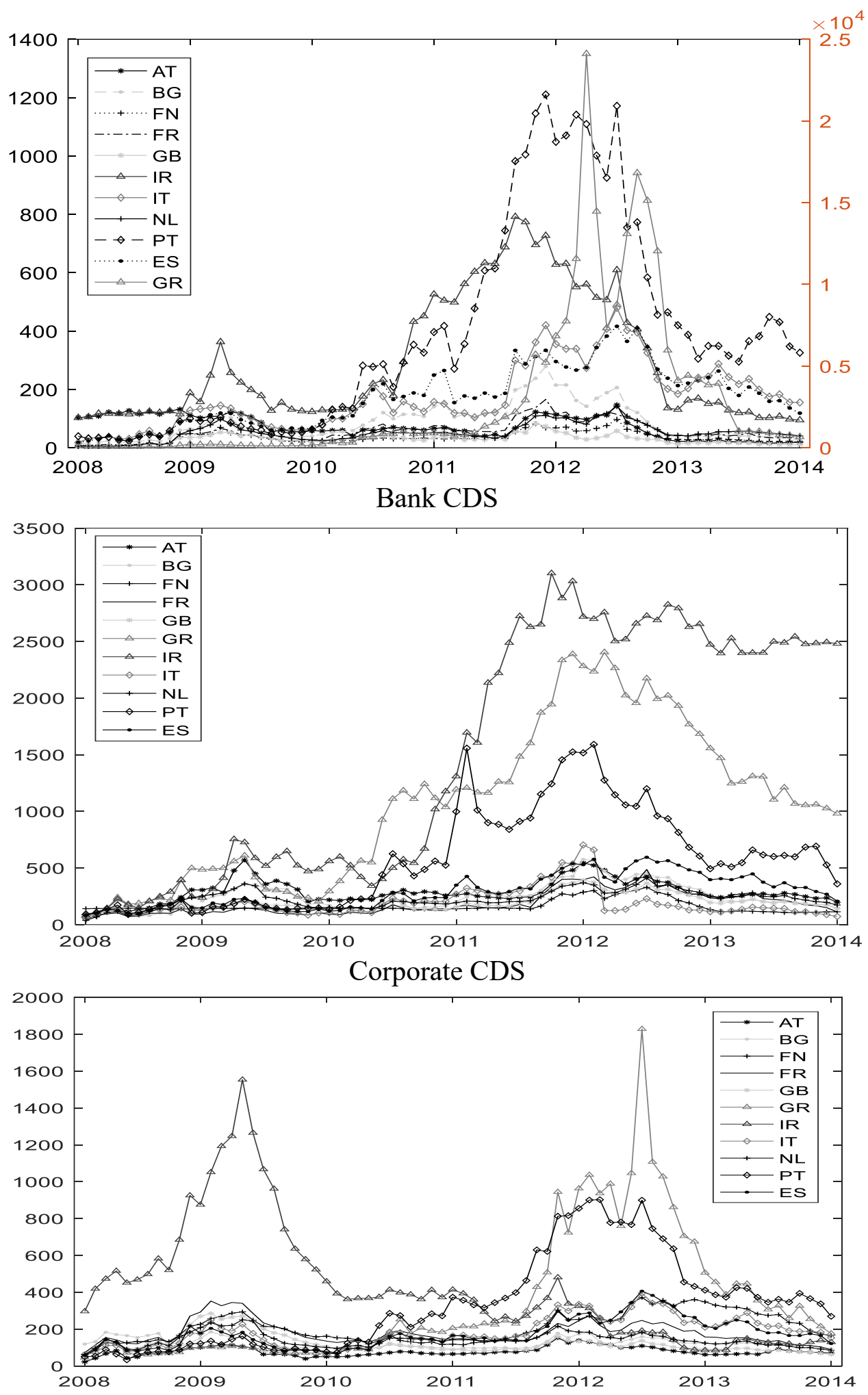
Table 1: Definition of cross-border interconnectedness

\begin{tabular}{lrrr}
\hline & $\begin{array}{r}\text { Sovereign } \\
(\mathbf{j = 1})\end{array}$ & $\begin{array}{r}\text { Bank } \\
(\mathbf{j}=\mathbf{2})\end{array}$ & $\begin{array}{r}\text { Corporate } \\
(\mathbf{j}=\mathbf{3})\end{array}$ \\
\hline $\begin{array}{l}\text { Sovereign } \\
(k=1)\end{array}$ & Trade + Bank Exposure & Bank Exposure & Trade Flow \\
$\begin{array}{l}\text { Bank } k=2) \\
\begin{array}{l}\text { Corporate } \\
(k=3)\end{array}\end{array}$ & Bank Exposure & Bank Exposure & Bank Exposure \\
\hline
\end{tabular}




\section{Table 2: Descriptive statistics}

Note: G stands for log-differenced sovereign CDS spreads in the eleven Euro area countries from 2008M1 to 2013M12. B stands for log-differenced banking CDS spreads. C stands for log-differenced corporate CDS spreads. The CIPS statistic is based on cross-sectionally augmented Dickey-Fuller regression with intercept, cross-sectional dependence and serial dependence (Pesaran, 2007). H0: one unit root. CIPS stands for the CIPS test for the log-differenced sovereign, banking, and corporate CDS spreads. CIPS_level stands for the CIPS test for the logged sovereign, banking and corporate CDS spreads.

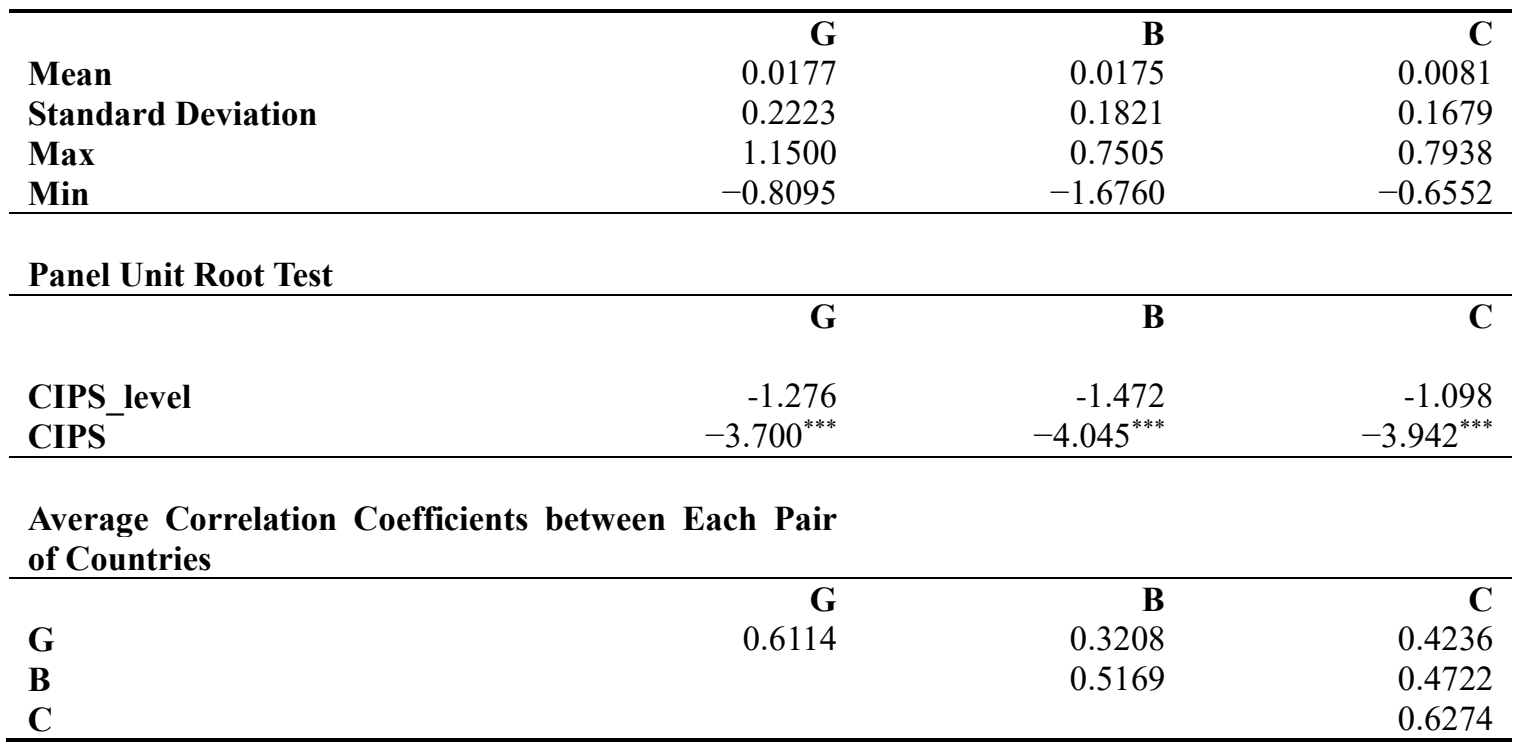




\section{Table 3: Restricted SpVAR model estimation results}

Note: Estimation is for the 2008M1-2013M12 period based on Equation (1). Insignificant coefficients are restricted to be zero in this estimation. $G$ stands for log-differenced sovereign CDS spreads. B stands for log-differenced banking CDS spreads. C stands for log-differenced corporate CDS spreads. $\rho$ is the contemporaneous spatial coefficient, $\mathrm{W}$ is defined on the basis of bilateral trade and/or bank exposure, as defined in section 2.2. $\gamma$ stands for coefficients of contemporaneous domestic variables. $\phi$ stands for autoregressive coefficients for lagged domestic variables. ' $\overline{\mathrm{R}}^{2}$ _no spatial term' and 'BIC_no spatial term' report the adjusted $\mathrm{R}$ squared and BIC for the restricted panel model without spatial dependence. LM_serial (Baltagi \& Li, 1991) tests for time series autocorrelation in the error terms till 12 lags with H0 of 'no series autocorrelation'. LM_spatial (Anselin, 1988) stands for the Lagrange multiplier, which tests for spatial autocorrelation in the error terms with $\mathrm{H} 0$ of 'no spatial autocorrelation'. 90\% Bayesian credible intervals are given in parentheses. Unrestricted SpVAR with full parameters are available from the author on request.

\begin{tabular}{|c|c|c|c|}
\hline Model 1 & $\begin{array}{r}G \\
(j=1)\end{array}$ & $\begin{array}{r}\text { B } \\
(j=2) \\
\end{array}$ & $\begin{array}{r}\mathrm{C} \\
(j=3) \\
\end{array}$ \\
\hline \multicolumn{4}{|l|}{$\rho$} \\
\hline $\mathbf{W} * \mathbf{G}$ & $\begin{array}{r}0.613 \\
{[0.581 ; 0.643]}\end{array}$ & - & - \\
\hline $\mathbf{W} * \mathbf{B}$ & & $\begin{array}{r}0.629 \\
{[0.591 ; 0.668]}\end{array}$ & $\begin{array}{r}0.212 \\
{[0.167 ; 0.257]}\end{array}$ \\
\hline $\mathbf{W} * \mathbf{C}$ & - & - & $\begin{array}{r}0.629 \\
{[0.579 ; 0.677]}\end{array}$ \\
\hline \multicolumn{4}{|c|}{ - } \\
\hline G_0 & - & $\begin{array}{r}0.081 \\
{[0.046 ; 0.113]}\end{array}$ & - \\
\hline B_0 & $\begin{array}{r}0.086 \\
{[0.043 ; 0.132]}\end{array}$ & - & - \\
\hline C_0 & $\begin{array}{r}0.201 \\
{[0.156 ; 0.247]}\end{array}$ & - & - \\
\hline \multicolumn{4}{|l|}{$\varphi$} \\
\hline G_1 & - & $\begin{array}{r}0.049 \\
{[0.010 ; 0.091]}\end{array}$ & - \\
\hline B_1 & - & - & - \\
\hline C_1 & - & - & - \\
\hline \multicolumn{4}{|l|}{$\beta$} \\
\hline VIX_1 & $\begin{array}{r}0.085 \\
{[0.053 ; 0.202]}\end{array}$ & - & - \\
\hline EU stock_1 & - & $\begin{array}{r}-0.506 \\
{[-0.644 ;-0.365]}\end{array}$ & $\begin{array}{r}-1.078 \\
{[-1.247 ;-0.905]}\end{array}$ \\
\hline Euribor-Eonia spread_1 & - & - & - \\
\hline $\begin{array}{l}\text { Eonia-German T-Bill } \\
\text { spread_1 }\end{array}$ & - & - & - \\
\hline Exchange rate_1 & $\begin{array}{r}-1.083 \\
{[-1.253 ;-0.910]}\end{array}$ & $\begin{array}{r}-0.591 \\
{[-0.770 ;-0.415]}\end{array}$ & $\begin{array}{r}-0.427 \\
{[-0.606 ;-0.244]}\end{array}$ \\
\hline Bad news_1 & $\begin{array}{r}0.112 \\
{[0.092 ; 0.133]}\end{array}$ & $\begin{array}{r}0.084 \\
{[0.064 ; 0.105]}\end{array}$ & $\begin{array}{r}0.081 \\
{[0.060 ; 0.102]}\end{array}$ \\
\hline Country-specific intercept & Yes & Yes & Yes \\
\hline $\bar{R}^{2}$ & 0.5230 & & -0.3366 \\
\hline
\end{tabular}




\begin{tabular}{lrlr}
$\bar{R}^{2} \_$no spatial term & 0.1928 & BIC_no spatial term & 0.1523 \\
LM_serial & 2.03 & LM_spatial & 0.4234 \\
No. of Obs. & 2310 & No. of Var. & 60 \\
\hline
\end{tabular}


Table 4: Error variance decomposition of sovereign, banking, and corporate default risks:

$$
\mathbf{T}=\mathbf{1 0}
$$

Note: This table shows the forecast error variance decomposition based on Equation (1). W is defined on the basis of bilateral trade and/or bank exposure, as specified in section 2.2. The variance decomposition is based on restricted SpVAR where insignificant parameters are excluded. In panel 2, the shocks are further restricted to exogenous shocks using the structural impulse response function proposed by den Haan, Sumner \& Yamashiro (2007). The values are the average proportion of the variance of the eleven countries predicted by the respective shocks. The absolute level of variance is reported in the round brackets. The $90 \%$ confidence interval based on 200 randomly generated weight matrices is reported in square brackets. When the predicted variance is above the upper bound of the $90 \%$ confidence, the cell is bonded.

\begin{tabular}{|c|c|c|c|c|c|c|}
\hline & $\begin{array}{r}\text { Domestic } \\
\text { Sovereign } \\
\text { Shock } \\
\end{array}$ & $\begin{array}{r}\text { Foreign } \\
\text { Sovereign } \\
\text { Shock } \\
\end{array}$ & $\begin{array}{r}\text { Domestic } \\
\text { Banking Shock }\end{array}$ & $\begin{array}{r}\text { Foreign } \\
\text { Banking Shock }\end{array}$ & $\begin{array}{r}\text { Domestic } \\
\text { Corporate } \\
\text { Shock } \\
\end{array}$ & $\begin{array}{r}\text { Foreign } \\
\text { Corporate } \\
\text { Shock } \\
\end{array}$ \\
\hline \multicolumn{7}{|c|}{ Panel 1: Restricted generalized impulse response function with insignificant parameters setting as zero } \\
\hline $\begin{array}{l}\text { Sovereign } \\
\text { CDS } \\
\text { change }\end{array}$ & $\begin{array}{r}62 \% \\
(0.0357) \\
{[0.0269 ; 0.0354]}\end{array}$ & $\begin{array}{r}20 \% \\
(0.0111) \\
{[0.0028 ; 0.0104]}\end{array}$ & $\begin{array}{r}3 \% \\
(0.0017) \\
{[0.0001 ; 0.0012]}\end{array}$ & $\begin{array}{r}7 \% \\
(0.0041) \\
{[0.0002 ; 0.0025]}\end{array}$ & $\begin{array}{r}3 \% \\
(0.0018) \\
{[0.0005 ; 0.0031]}\end{array}$ & $\begin{array}{r}5 \% \\
(0.0025) \\
{[0.0008 ; 0.0063]}\end{array}$ \\
\hline $\begin{array}{l}\text { Banking } \\
\text { CDS } \\
\text { change }\end{array}$ & $\begin{array}{r}2 \% \\
(0.0009) \\
{[0.0005 ; 0.0014]}\end{array}$ & $\begin{array}{r}3 \% \\
(0.0012) \\
{[0.0005 ; 0.0030]}\end{array}$ & $\begin{array}{r}69 \% \\
(0.0260) \\
{[0.0181 ; 0.0221]}\end{array}$ & $\begin{array}{r}24 \% \\
(0.0088) \\
{[0.0007 ; 0.0034]}\end{array}$ & $\begin{array}{r}0 \% \\
(0.0001) \\
{[0.0001 ; 0.0015]}\end{array}$ & $\begin{array}{r}1 \% \\
(0.0002) \\
{[0.0004 ; 0.0036]}\end{array}$ \\
\hline $\begin{array}{l}\text { Corporate } \\
\text { CDS } \\
\text { change } \\
\end{array}$ & $\begin{array}{r}0 \% \\
(0.0001) \\
{[0.0001 ; 0.0009]} \\
\end{array}$ & $\begin{array}{r}2 \% \\
(0.0005) \\
{[0.0002 ; 0.0030]} \\
\end{array}$ & $\begin{array}{r}4 \% \\
(0.0013) \\
{[0.0001 ; 0.0008]} \\
\end{array}$ & $\begin{array}{r}19 \% \\
(0.0056) \\
{[0.0001 ; 0.0016]} \\
\end{array}$ & $\begin{array}{r}56 \% \\
(0.0168) \\
{[0.0141 ; 0.0178]} \\
\end{array}$ & $\begin{array}{r}19 \% \\
(0.0054) \\
{[0.0016 ; 0.0058]} \\
\end{array}$ \\
\hline
\end{tabular}

Panel 2: Structured variance decomposition proposed by den Haan, Sumner, \& Yamashiro (2007) for strictly exogenous shocks

\begin{tabular}{|c|c|c|c|c|c|c|}
\hline $\begin{array}{l}\text { Sovereign } \\
\text { CDS } \\
\text { change }\end{array}$ & $\begin{array}{r}61 \% \\
(0.0348) \\
{[0.0298 ; 0.0378]}\end{array}$ & $\begin{array}{r}18 \% \\
(0.0106) \\
{[0.0031 ; 0.0096]}\end{array}$ & $\begin{array}{r}3 \% \\
(0.0017) \\
{[0.0001 ; 0.0011]}\end{array}$ & $\begin{array}{r}7 \% \\
(0.0039) \\
{[0.0002 ; 0.0021]}\end{array}$ & $\begin{array}{r}3 \% \\
(0.0018) \\
{[0.0005 ; 0.0031]}\end{array}$ & $\begin{array}{r}4 \% \\
(0.0025) \\
{[0.0008 ; 0.0057]}\end{array}$ \\
\hline $\begin{array}{l}\text { Banking } \\
\text { CDS } \\
\text { change }\end{array}$ & $\begin{array}{r}2 \% \\
(0.0009) \\
{[0.0005 ; 0.0012]}\end{array}$ & $\begin{array}{r}3 \% \\
(0.0012) \\
{[0.0005 ; 0.0026]}\end{array}$ & $\begin{array}{r}68 \% \\
(0.0254) \\
{[0.0197 ; 0.0233]}\end{array}$ & $\begin{array}{r}23 \% \\
(0.0084) \\
{[0.0011 ; 0.0036]}\end{array}$ & $\begin{array}{r}0 \% \\
(0.0001) \\
{[0.0001 ; 0.0016]}\end{array}$ & $\begin{array}{r}1 \% \\
(0.0002) \\
{[0.0004 ; 0.0041]}\end{array}$ \\
\hline $\begin{array}{l}\text { Corporate } \\
\text { CDS } \\
\text { change }\end{array}$ & $\begin{array}{r}0 \% \\
(0.0001) \\
{[0.0001 ; 0.0013]}\end{array}$ & $\begin{array}{r}2 \% \\
(0.0005) \\
{[0.0002 ; 0.0034]}\end{array}$ & $\begin{array}{r}4 \% \\
(0.0012) \\
{[0.0001 ; 0.0006]}\end{array}$ & $\begin{array}{r}18 \% \\
(0.0054) \\
{[0.0001 ; 0.0017]}\end{array}$ & $\begin{array}{r}55 \% \\
(0.0164) \\
{[0.0145 ; 0.0188]}\end{array}$ & $\begin{array}{r}18 \% \\
(0.0052) \\
{[0.0018 ; 0.0090]}\end{array}$ \\
\hline
\end{tabular}


Table 5: Error variance decomposition of sovereign, banking, and corporate default risks: $T$ $=\mathbf{1 0}$

Note: This table shows the forecast error variance decomposition based on Equation (1) using alternative definition of weight matrices. Detailed definition is in online Appendix 6. The variance decomposition is based on restricted SpVAR where insignificant parameters are excluded. The shocks are restricted to strictly exogenous shocks using the structured impulse response function proposed by den Haan, Sumner, $\&$ Yamashiro (2007). The values are the average proportion of the variance of the eleven countries predicted by the respective shocks. The absolute level of variance is reported in the round brackets. The $90 \%$ confidence interval based on 200 randomly generated weight matrices is in Panel 2 of Table 4 . When the predicted variance is above the upper bound of the $90 \%$ confidence, the cell is bonded.

\begin{tabular}{lrrrrrr}
\hline & $\begin{array}{r}\text { Domestic } \\
\text { Sovereign } \\
\text { Shock }\end{array}$ & $\begin{array}{r}\text { Foreign } \\
\text { Sovereign } \\
\text { Shock }\end{array}$ & $\begin{array}{r}\text { Domestic } \\
\text { Banking } \\
\text { Shock }\end{array}$ & $\begin{array}{r}\text { Foreign } \\
\text { Banking } \\
\text { Shock }\end{array}$ & $\begin{array}{r}\text { Domestic } \\
\text { Corporate } \\
\text { Shock }\end{array}$ & $\begin{array}{r}\text { Foreign } \\
\text { Corporate } \\
\text { Shock }\end{array}$ \\
\hline Model 2: ECB Sectoral & & & & & & \\
Bank Claim Data and trade & & & & & & \\
Sovereign CDS change & $63 \%$ & $17 \%$ & $2 \%$ & $\mathbf{4 \%}$ & $5 \%$ & $8 \%$ \\
& $(0.0341)$ & $(0.0094)$ & $(0.0010)$ & $\mathbf{( 0 . 0 0 2 1 )}$ & $(0.0027)$ & $(0.0045)$ \\
Banking CDS change & $2 \%$ & $3 \%$ & $\mathbf{6 6 \%}$ & $\mathbf{1 3 \%}$ & $5 \%$ & $8 \%$ \\
& $(0.0008)$ & $(0.0009)$ & $\mathbf{( 0 . 0 2 1 4 )}$ & $\mathbf{( 0 . 0 0 4 2 )}$ & $(0.0018)$ & $(0.0024)$ \\
Corporate CDS change & $0 \%$ & $1 \%$ & $\mathbf{1 \%}$ & $\mathbf{7 \%}$ & $61 \%$ & $27 \%$ \\
& $(0.0001)$ & $(0.0002)$ & $\mathbf{( 0 . 0 0 0 4 )}$ & $\mathbf{( 0 . 0 0 2 0})$ & $(0.0187)$ & $(0.0080)$ \\
\hline
\end{tabular}

Model 3: Trade and

Portfolio

Sovereign CDS change

$59 \% \quad \mathbf{1 7 \%}$

Banking CDS change

(0.0339)

(0.0097)

$2 \%$

$5 \%$

(0.0012)

(0.0029)

$5 \%$

$60 \%$

$20 \%$

(0.0010)

(0.0014)

(0.0240)

Corporate CDS change

$(0.0001)$

$1 \%$

$2 \%$

(0.0079)

9\%

(0.0006)

(0.0029)

$(0.0029)$

$(0.0003)$

$(0.0029)$

$(0.0015) \quad(0.0026)$

$58 \% \quad 28 \%$

(0.0193)

$(0.0089)$

Model 4: FDI and Bank

Sovereign CDS change

Banking CDS change

Corporate CDS change

\begin{tabular}{rrrrrr}
$64 \%$ & $20 \%$ & $\mathbf{3 \%}$ & $\mathbf{5 \%}$ & $4 \%$ & $4 \%$ \\
$(0.0345)$ & $(0.0105)$ & $\mathbf{( 0 . 0 0 1 6 )}$ & $\mathbf{( 0 . 0 0 2 9 )}$ & $(0.0019)$ & $(0.0022)$ \\
$4 \%$ & $5 \%$ & $\mathbf{6 7 \%}$ & $\mathbf{1 9 \%}$ & $2 \%$ & $1 \%$ \\
$(0.0013)$ & $(0.0017)$ & $\mathbf{( 0 . 0 2 3 2})$ & $\mathbf{( 0 . 0 0 6 3 )}$ & $(0.0006)$ & $(0.0004)$ \\
$1 \%$ & $2 \%$ & $\mathbf{3 \%}$ & $\mathbf{1 4 \%}$ & $57 \%$ & $19 \%$ \\
$(0.0002)$ & $(0.0006)$ & $\mathbf{( 0 . 0 0 0 9 )}$ & $\mathbf{( 0 . 0 0 4 0 )}$ & $(0.0159)$ & $(0.0054)$ \\
\hline
\end{tabular}

Model 5: Openness

Sovereign CDS change

(0.0009)

(0.0040)

(0.0159)

\begin{tabular}{lrrrrrr} 
& $(0.0339)$ & $\mathbf{( 0 . 0 1 4 5 )}$ & $\mathbf{( 0 . 0 0 2 2})$ & $\mathbf{( 0 . 0 0 3 6})$ & $(0.0000)$ & $(0.0000)$ \\
Banking CDS change & $0 \%$ & $0 \%$ & $\mathbf{7 1 \%}$ & $\mathbf{2 6 \%}$ & $0 \%$ & $0 \%$ \\
& $(0.0000)$ & $(0.0000)$ & $\mathbf{( 0 . 0 2 4 4 )}$ & $\mathbf{( 0 . 0 0 8 9})$ & $(0.0000)$ & $(0.0000)$ \\
Corporate CDS change & $0 \%$ & $0 \%$ & $0 \%$ & $0 \%$ & $65 \%$ & $32 \%$ \\
& $(0.0000)$ & $(0.0000)$ & $(0.0000)$ & $(0.0000)$ & $(0.0184)$ & $(0.0090)$ \\
\hline
\end{tabular}

Model 6: Distance

Sovereign CDS change

Banking CDS change

$(0.0303)$

$65 \% \quad 16 \%$

Banking CDS change

Corporate CDS change

$2 \% \quad 3 \%$

$4 \%$
$(0.0020)$

$71 \%$

$8 \%$

(0.0036)

$23 \%$

(0.0006)

(0.0010)

(0.0233)

(0.0075)

(0.0010)

$5 \%$

$0 \%$

$0 \%$

$0 \%$

$0 \%$

$(0.0000)$

$1 \%$

$(0.0000)$

$(0.0000)$

$(0.0000)$

(0.0000)

(0.0177)

(0.0002)

$32 \%$

(0.0085) 


\section{Table 6: Estimation results of distance decay model}

Notes: Estimation is for the 2008M1-2013M12 period based on Equation (11). G stands for logdifferenced sovereign CDS spreads. B stands for log-differenced banking CDS spreads. $C$ stands for logdifferenced corporate CDS spreads. W is defined on the basis of bilateral trade and/or bank exposure, as specified in section 2.2, but is split into neighbors and non-neighbors. Only spatial coefficients are reported. 90\% Bayesian credible intervals are given in parentheses. ${ }^{a}$ denotes that the null hypothesis of 'insignificant parameter' can be rejected at $5 \%$ level.

\begin{tabular}{|c|c|c|c|}
\hline Model 7 & $\begin{array}{r}G \\
(j=1) \\
\end{array}$ & $\begin{array}{r}\text { B } \\
(j=2) \\
\end{array}$ & $\begin{array}{r}\begin{array}{c}C \\
(j=3)\end{array} \\
\end{array}$ \\
\hline \multicolumn{4}{|l|}{$\rho$ nnei } \\
\hline W_nei *G & $\begin{array}{r}0.501^{\mathrm{a}} \\
{[0.445 ; 0.555]}\end{array}$ & $\begin{array}{r}-0.037 \\
{[-0.122 ; 0.035]}\end{array}$ & $\begin{array}{r}-0.023 \\
{[-0.116 ; 0.076]}\end{array}$ \\
\hline W_nei *B & $\begin{array}{r}-0.115 \\
{[-0.223 ;-0.027]}\end{array}$ & $\begin{array}{r}0.543^{\mathrm{a}} \\
{[0.467 ; 0.621]}\end{array}$ & $\begin{array}{r}0.201^{\mathrm{a}} \\
{[0.083 ; 0.313]}\end{array}$ \\
\hline W_nei *C & $\begin{array}{r}0.001 \\
{[-0.133 ; 0.136]}\end{array}$ & $\begin{array}{r}-0.105 \\
{[-0.225 ; 0.001]}\end{array}$ & $\begin{array}{r}0.664^{\mathrm{a}} \\
{[0.571 ; 0.763]}\end{array}$ \\
\hline \multicolumn{4}{|l|}{$\rho \_$non_nei } \\
\hline$W_{-}$non_nei *G & $\begin{array}{r}0.126^{\mathrm{a}} \\
{[0.070 ; 0.196]}\end{array}$ & $\begin{array}{r}0.010 \\
{[-0.066 ; 0.070]}\end{array}$ & $\begin{array}{r}0.057 \\
{[-0.016 ; 0.138]}\end{array}$ \\
\hline W_non_nei *B & $\begin{array}{r}0.040 \\
{[-0.033 ; 0.104]}\end{array}$ & $\begin{array}{r}0.071^{\mathrm{a}} \\
{[0.011 ; 0.130]}\end{array}$ & $\begin{array}{r}0.015 \\
{[-0.056 ; 0.098]}\end{array}$ \\
\hline W_non_nei *C & $\begin{array}{r}-0.083 \\
{[-0.172 ; 0.011]}\end{array}$ & $\begin{array}{r}-0.047 \\
{[-0.139 ; 0.039]}\end{array}$ & $\begin{array}{r}-0.119 \\
{[-0.202 ; 0.015]}\end{array}$ \\
\hline
\end{tabular}

\section{Online Appendices}

\section{Appendix 1: Bayesian estimation of SpVAR}

The SpVAR model is estimated by means of a Bayesian estimator for multivariate spatial regression models (Gamerman \& Moreira, 2004). The estimation is based on the spatial econometric toolbox presented by LeSage (LeSage, 1997; LeSage \& Parent, 2007):

$Y=\left\{I_{T} \otimes\left[\left(\mathrm{P} \otimes 1_{N}\right)\right] \circ \mathbf{W}+I_{T} \otimes\left(\Gamma \otimes 1_{N}\right)\right\} Y+Z \xi+e$,

where $Y$ is an $N K T \times 1$ vector of the CDS growth rate, stacked first by country, then by variable, and then by time period. $N$ stands for total country, $K$ for total number of variables, and T for total 
number of periods. $\mathbf{W}$ is a block-diagonal $N K T \times N K T$ matrix, and $\mathbf{W}=\left(\begin{array}{ccc}\mathbf{W}_{1} & & \\ & \ddots & \\ & & \mathbf{W}_{T}\end{array}\right)$. For each diagonal element $\mathbf{W}_{t}=\left(\boldsymbol{W}_{\boldsymbol{t}}^{\boldsymbol{j}, \boldsymbol{k}}\right), j=1, . ., K, k=1, \ldots, K$. Each $\boldsymbol{W}_{\boldsymbol{t}}^{\boldsymbol{j}, \boldsymbol{k}}$ is an $N \times N$ matrix, and is defined based on the interconnectedness (e.g., bilateral trade or bank exposure) between each pair of countries. The diagonal elements are zero. $\mathrm{P}$ is a matrix. $1_{N}$ is a $N \times N$ vector with all elements as 1 , and $I_{T}$ is a $T \times T$ identity matrix. $\circ$ denotes entrywise product. $I_{T} \otimes\left[\left(\mathrm{P} \otimes 1_{N}\right)\right] \circ$ $\mathbf{W}=\left(\begin{array}{lll}\left(\mathrm{P} \otimes 1_{N}\right) \circ \mathbf{W}_{1} & & \\ & \ddots & \\ & & \left(\mathrm{P} \otimes 1_{N}\right) \circ \mathbf{W}_{T}\end{array}\right) \cdot$ Each diagonal element $\quad\left(\mathrm{P} \otimes 1_{N}\right) \circ \mathbf{W}_{t}=$ $\left(\begin{array}{ccc}\rho_{1,1} W_{t}^{1,1} & \cdots & \rho_{1, K} W_{t}^{1, K} \\ \vdots & \ddots & \vdots \\ \rho_{K, 1} W_{t}^{K, 1} & \cdots & \rho_{K, K} W_{t}^{K, K}\end{array}\right) . \Gamma$ is a $\mathrm{K} \times \mathrm{K}$ matrix with zero diagonal element.

$Z$ includes all explanatory variables. $\xi$ is the coefficient vector. $e \sim N\left(0, I_{T} \otimes\left(\Sigma_{K} \otimes I_{N}\right)\right)$, and $\Sigma_{K}$ is a $K \times K$ matrix.

Equation (A1) can be rewritten as:

$\Xi Y=Z \xi+e$,

with $\Xi=I_{N K T}-I_{T} \otimes\left[\left(\mathrm{P} \otimes 1_{N}\right)\right] \circ \mathbf{W}-I_{T} \otimes\left(\Gamma \otimes 1_{N}\right)$. Let $\tilde{Z}=\Theta^{-1} Z, \widetilde{Y}=\Theta^{-1} Y$, (A2) can then be transformed as:

$\Xi \widetilde{Y}=\tilde{Z} \xi+u$ with $u \sim N(0, \Lambda)$,

where $\Lambda=\Theta^{-1}\left[I_{T} \otimes\left(\Sigma_{K} \otimes I_{N}\right)\right] \Theta^{-1 \prime}$. Gamerman and Moreira (2004) suggest priors for the spatial autoregressive parameter $\mathrm{P}$, parameters $\xi$, and the covariance matrix $\Sigma_{K}$. The prior for $\left(\xi, \Sigma_{K}\right)$ follows a multivariate normal inverse Wishart form, as follows:

$\left(\xi, \Sigma_{K}\right) \sim N I W\left(c_{0}, C_{0}, v_{0}, S_{0}\right)$. 
For $\xi$, a diffuse prior is implemented by setting the prior mean $\mathrm{c}$ to zero and the prior variance of $\mathrm{C}$ to $1 \mathrm{e}+12 . v_{0}$ is set as $K$, and $v_{0} S_{0}$ is set as $(1 \mathrm{e}-12) I_{K}$.

Regarding P and $\Gamma$, Gamerman and Moreira (2004) state that there is no obvious suggestion for the prior. In their empirical section, they use an independent, identical, normal distribution for each $\rho$ and $\gamma$, with a prior mean of 0 , and a prior variance of $1 \mathrm{e}+12$.

The log-likelihood function for the equation is:

$L L\left(P, \Gamma, \Sigma_{K}, \xi \mid Y, Z, \mathbf{W}\right) \propto \ln |\Xi|-N T \ln \left|\Sigma_{K}\right|-\frac{1}{2}[\Xi Y-Z \xi]^{\prime}\left[I_{T} \otimes\left(\Sigma_{K} \otimes I_{N}\right)\right][\Xi Y-Z \xi]$.

The conditional distribution for $\xi$, assuming $\Sigma_{K}, \mathrm{P}$ and $\Gamma$ are known, would be:

$\xi \mid\left(\mathrm{P}, \Gamma, \Sigma_{K}, Z, Y\right) \sim N\left(\widehat{\xi}_{1}, Q\right)$,

$\widehat{\xi_{1}}=Q\left[\tilde{Z}^{\prime}(\Xi \widetilde{Y})+C_{0}^{-1} c_{0}\right]$,

$Q=\left(\tilde{Z}^{\prime} \tilde{Z}+C_{0}^{-1}\right)$

The conditional distribution for $\Sigma_{K}$, assuming given $\xi, \Gamma$ and $\mathrm{P}$, would be:

$$
\begin{aligned}
& \Sigma_{K} \mid(\xi, \mathrm{P}, \Gamma, \mathrm{Z}, \mathrm{Y}) \sim N\left(v_{1}, s_{1}\right), \\
& v_{1}=v_{0}+N T, \\
& v_{1} S_{1}=v_{0} S_{0}+\left(\Xi \tilde{Y}-\tilde{Z} \xi_{1}\right)^{\prime}\left(\Xi \tilde{Y}-\tilde{Z} \xi_{1}\right)+\left(b_{1}-c_{0}\right)^{\prime} C_{0}^{-1}\left(b_{1}-c_{0}\right) .
\end{aligned}
$$

The estimation of $\mathrm{P}$ and $\Gamma$ is based on the posterior, following Metropolis-Hastings steps as follows:

$p\left(\mathrm{P}, \Gamma \mid \xi, \Sigma_{K}\right) \propto \ln |\Xi|-N T \ln \left|\Sigma_{K}\right|-\frac{1}{2}[\Xi \tilde{Y}-\tilde{Z} \xi]^{\prime}\left[I_{T} \otimes\left(\Sigma_{K} \otimes I_{N}\right)\right][\Xi \tilde{Y}-\tilde{Z} \xi]$,

and each $\rho$ and $\gamma$ is set in the range of: $\left(\frac{1}{\lambda_{\min }}, 1\right)$, where $\lambda_{\min }$ represents the minimum eigenvalue 
of the standardized W (LeSage, 1997; LeSage \& Parent, 2007). Gibbs sampling is run 2,200 times, with the first 200 samplings for initial values. Based on the convergence of coefficients in Appendix 3, a sample size of 2,000 is sufficient to provide good precision for the posterior mean estimate. 
Appendix 2: Data sources and definitions

\begin{tabular}{|c|c|c|}
\hline Variable & Source & Description \\
\hline Sovereign CDSs & Datastream & $\begin{array}{l}\text { CDS spreads for sovereigns. Default data for Greece after March } \\
2012 \text { come from Bloomberg. }\end{array}$ \\
\hline Bank CDSs & Datastream & $\begin{array}{l}\text { Capitalization-weighted aggregates for bank CDS spreads for } \\
\text { each country: } 3 \text { in AT, } 1 \text { in BE, } 1 \text { in FI, } 4 \text { in FR, } 10 \text { in DE, } 3 \text { in } \\
\text { GR, } 3 \text { in IR, } 8 \text { in IT, } 5 \text { in NL, } 2 \text { in PT, and } 7 \text { in ES. }\end{array}$ \\
\hline Corporate CDSs & Datastream & $\begin{array}{l}\text { Capitalization-weighted aggregates for corporate CDS spreads } \\
\text { for each country: } 1 \text { in AT, } 2 \text { in BE, } 7 \text { in FI, } 51 \text { in FR, } 36 \text { in DE, } 2 \\
\text { in GR, } 4 \text { in IR, } 12 \text { in IT, } 16 \text { in NL, } 3 \text { in PT, and } 8 \text { in ES. }\end{array}$ \\
\hline \multicolumn{3}{|l|}{ Control Variables } \\
\hline GDP & OECD & \\
\hline Credit-to-GDP Ratio & BIS & In percentage of GDP. \\
\hline Euro Stoxx 50 Index & Datastream & \\
\hline VIX Index & Datastream & \\
\hline Euribor-Eonia Spread & OECD & Difference between the Euribor and the Eonia rate. \\
\hline $\begin{array}{l}\text { Eonia-German T-bill } \\
\text { Spread }\end{array}$ & OECD & Difference between the Eonia and German T-bill yield. \\
\hline Good and Bad News & Zoli (2013) & Dummy variables for good and bad news. \\
\hline \multicolumn{2}{|l|}{ Weight Variables } & . \\
\hline Bilateral Trade & OECD & \\
\hline Bank Claims & BIS & Consolidated bank statistics of the BIS, Table 9B. \\
\hline $\begin{array}{l}\text { Foreign Direct } \\
\text { Investment }\end{array}$ & OECD & \\
\hline Portfolio Investment & IMF GIPS database & \\
\hline Openness Index & Heritage Foundation & $\begin{array}{l}\text { Based on the Index of Economic Freedom, which accounts for } \\
\text { trade, financial, and investment openness. }\end{array}$ \\
\hline Geographic Distance & & Measured as the straight line distance between capital cities. \\
\hline
\end{tabular}




\section{Appendix 3: Convergence of spatial dependence coefficients}
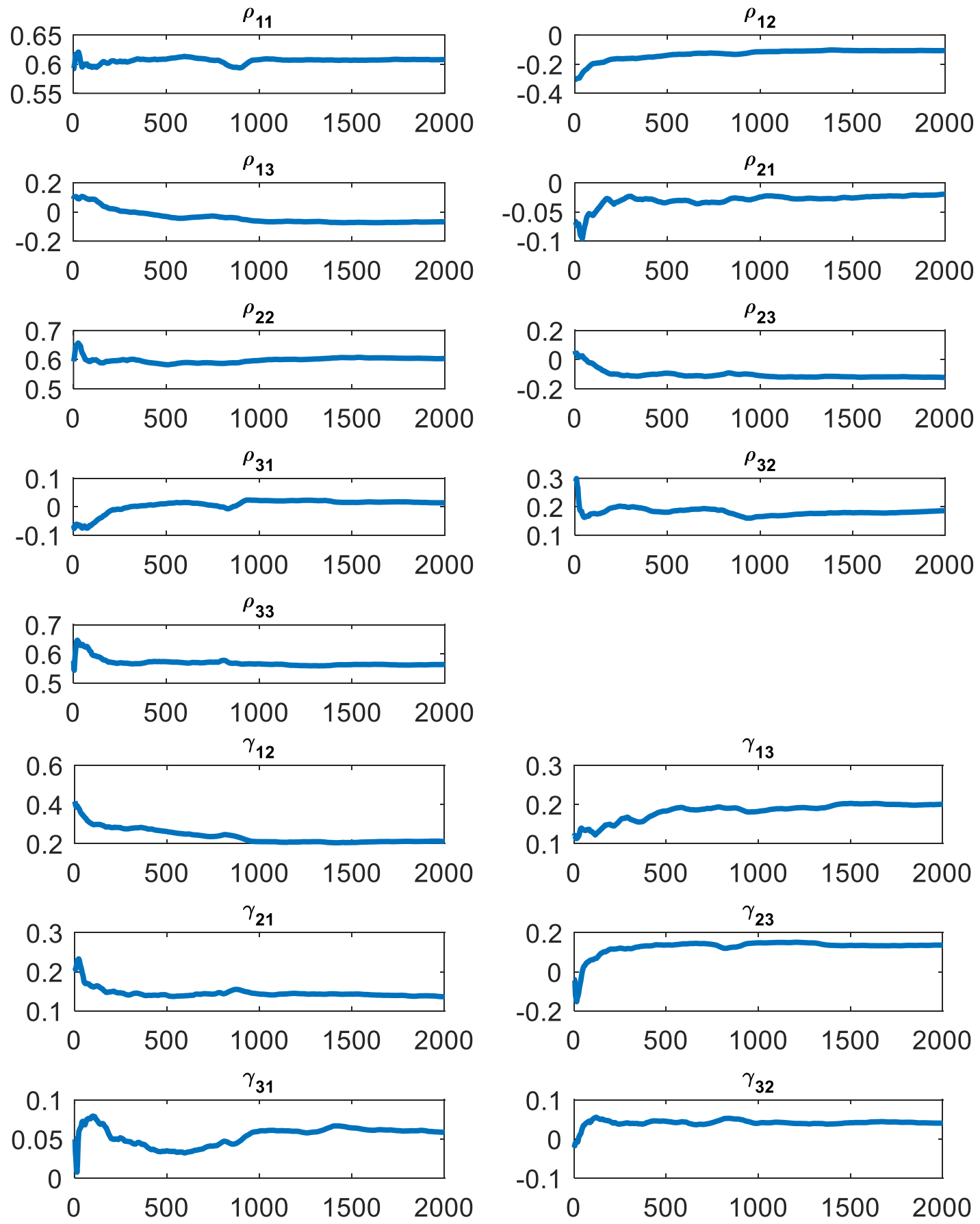

Note: The x-axes denote the number of samples; the y-axes denote the cumulative means of the corresponding coefficients. 
Appendix 4: Responses to 1-standard deviation sovereign, banking, and corporate shocks in Italy and Spain

Response of sovereign CDSs to sovereign shock

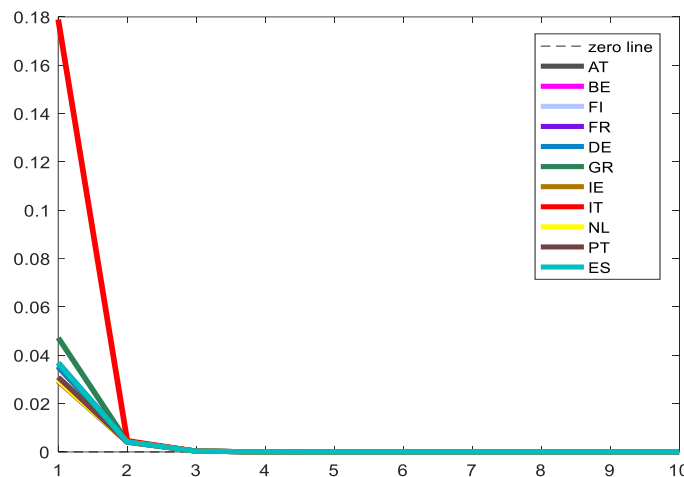

Response of sovereign CDSs to banking shock

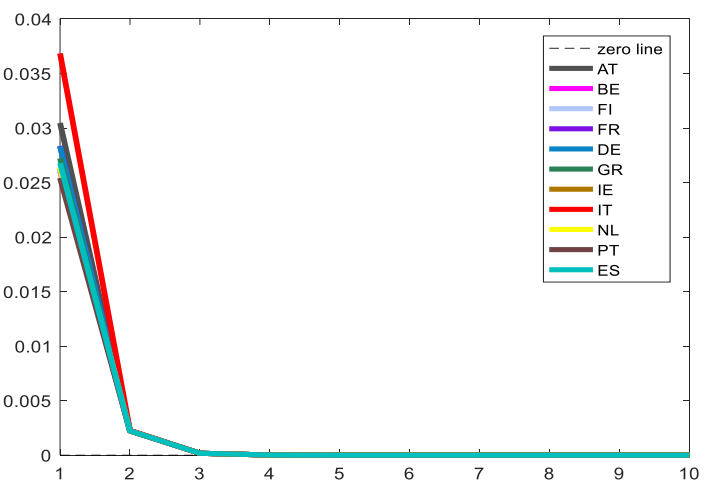

Response of sovereign CDSs to corporate shock

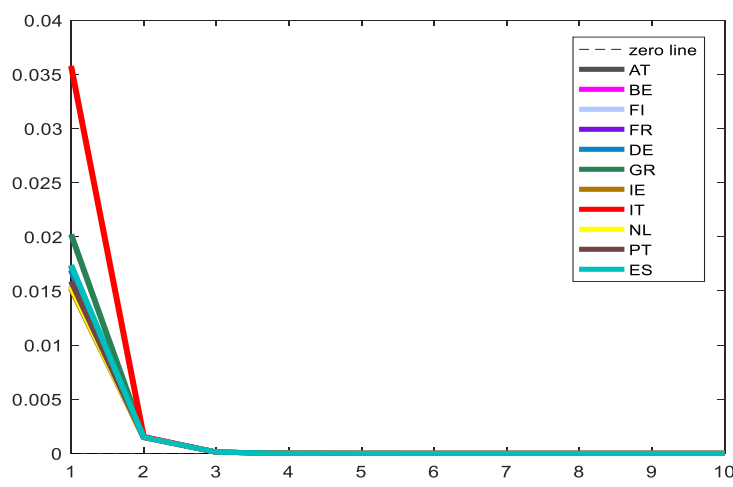

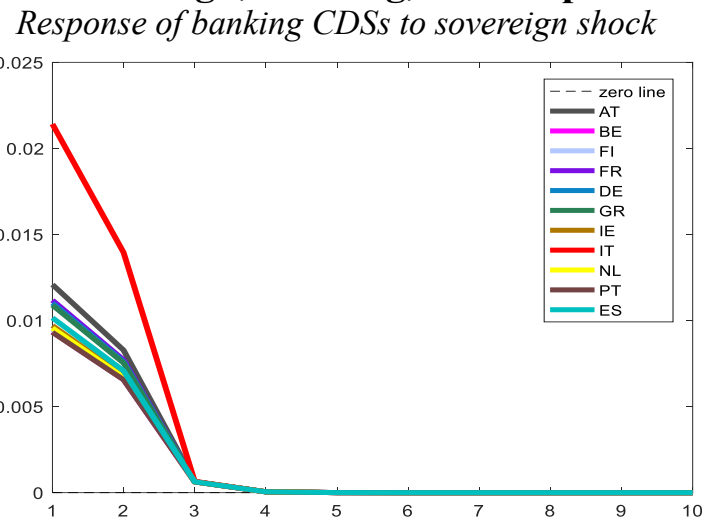

Response of banking CDSs to banking shock

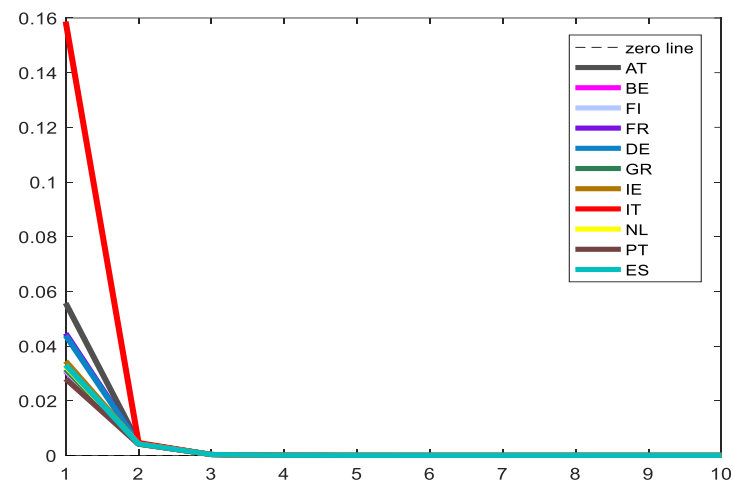

Response of banking CDSs to corporate shock

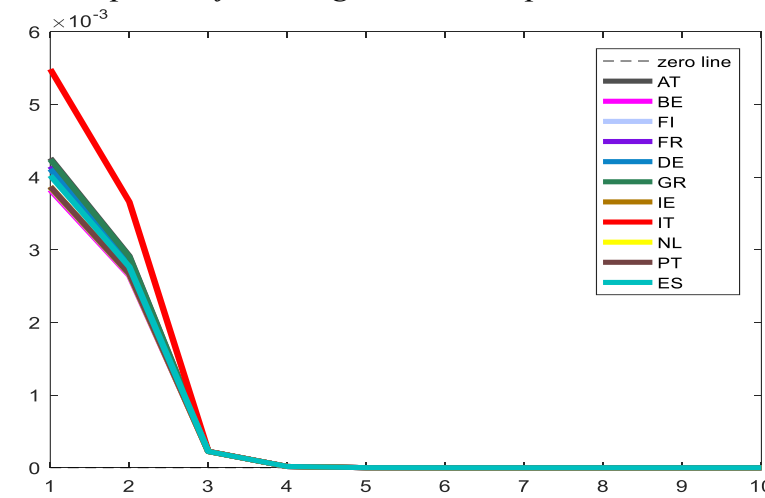

Response of corporate CDSs to sovereign shock

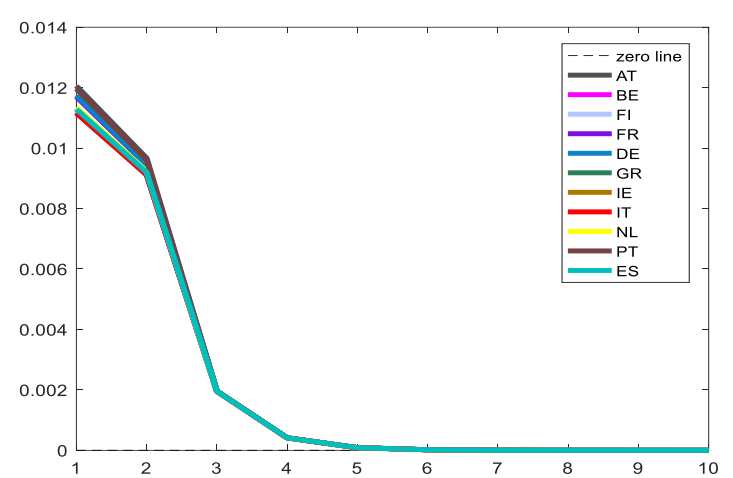

Response of corporate CDSs to banking shock

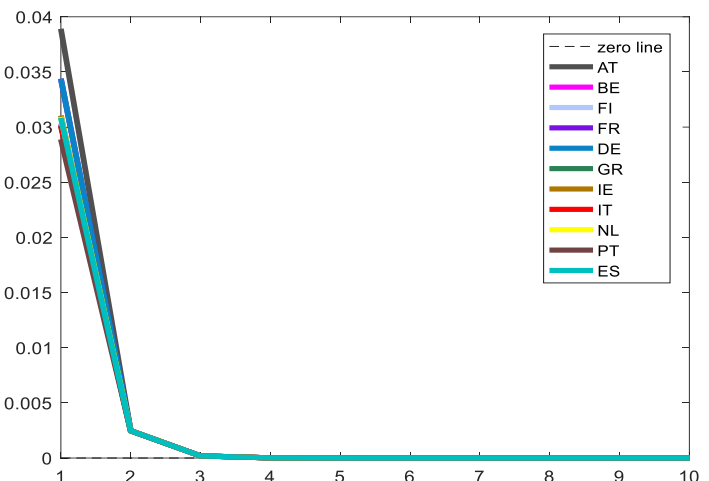

Response of corporate CDSs to corporate shock

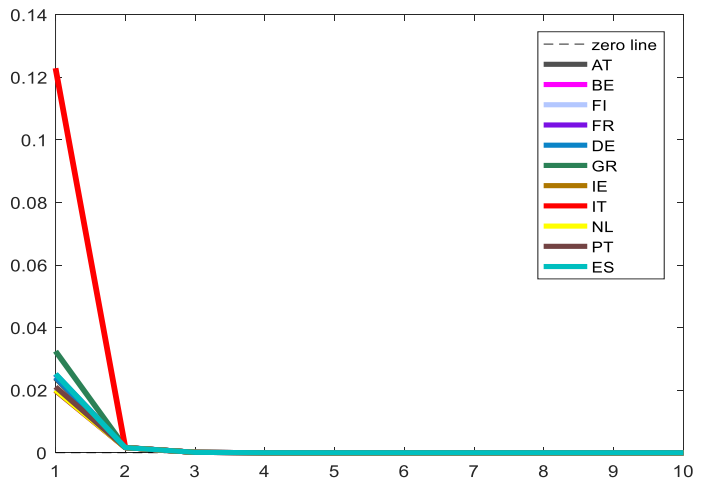




\section{Appendix 5: Table in-sample predictive accuracy for SpVAR model, Panel VAR model, and SpVAR model with 200 randomly generated matrices}

Note: This table reports the average sum squared errors (SSE), average pesudo R2 and average pesudo adjusted R2 as well as R2 for each specific country for sovereign CDS change equation, banking CDS change equation, and corporate CDS change equation. The SpVAR model refers to Equation (1). The VAR model refers to $y_{j, t}=\sum_{k=1, k \neq j}^{K} \gamma_{j, k} y_{k, t}+\sum_{q=1}^{Q} \sum_{k=1}^{K} \varphi_{j, k, q} y_{k, t-q}+\sum_{s=1}^{S} X_{t-s} \beta_{j, s}+D_{N} \alpha_{j}+e_{j, t}$. The SpVAR model in Part A is based on the weight matrix defined in Table 1. The SpVAR model in Part $C$ is based on 200 randomly generated matrices. Inside the square brackets are the upper and lower bounds for the $90 \%$ confidence interval of the corresponding evaluation criteria.

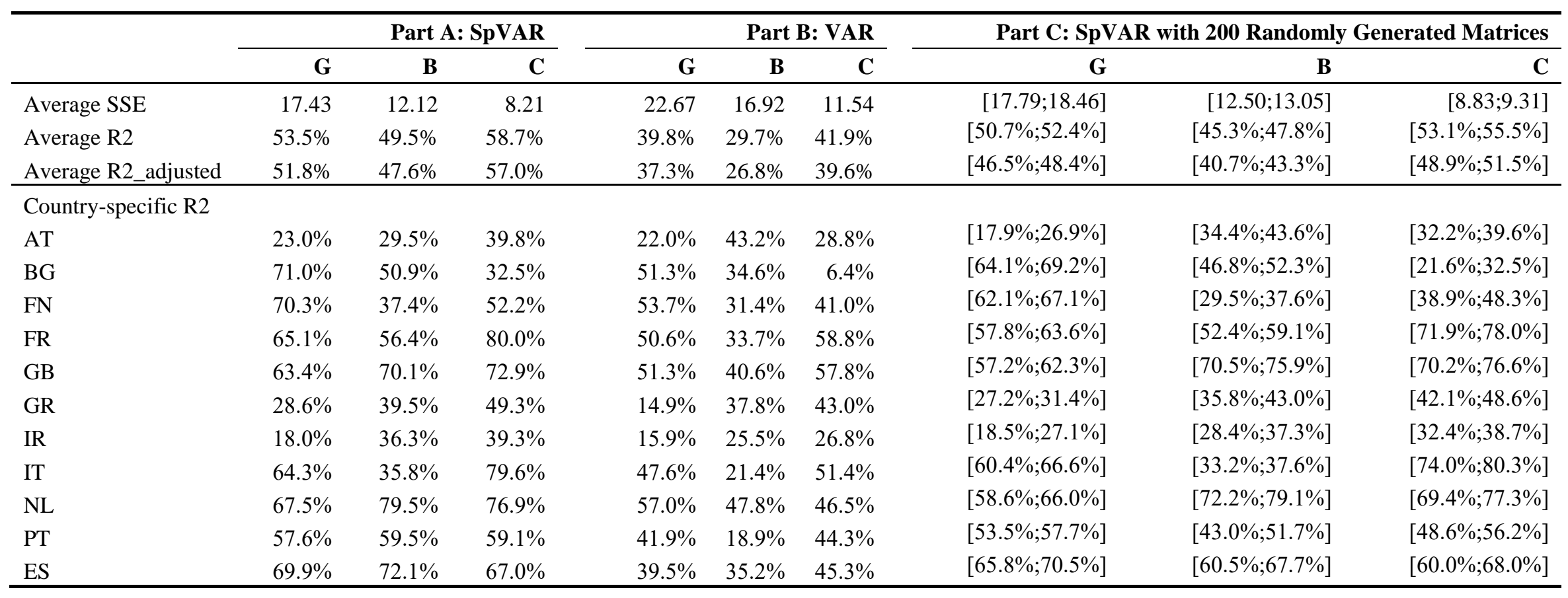




\section{Appendix 6: Alternative definition of weight matrix}

1) $\mathrm{EBA} / \mathrm{ECB} / \mathrm{SSM}$ sectoral bank exposure

Since 2011, EBA/ECB/SSM have published stress test datasets about bank claims, with detailed breakdowns of the bank's exposure vis-à-vis different segments, such as: other banks, nonfinancial private sectors, public sectors. The original data are for individual banks, and they are aggregated to the country level. The weights are defined according to the trade flow coming from the trade Statistics of the OECD and bank balance-sheet exposure come from EBA/ECB/SSM sectoral bank data.

\section{Table A6-1: Definition of cross-border interconnectedness}

Note: Export $\mathrm{h}_{\mathrm{h}, \mathrm{l}, \mathrm{t}-1}$ stands for the export from country 1 to country $\mathrm{h}$ in one month before period $\mathrm{t}$. $\mathrm{TB}_{\mathrm{h}, \mathrm{l}, \mathrm{t}-1}$ stands for the trade and bank exposures between country 1 and $\mathrm{h}$, where $\mathrm{TB}_{\mathrm{h}, \mathrm{l}, \mathrm{t}-1}=$ Export $_{\mathrm{h}, \mathrm{l}, \mathrm{t}-1}+$ Claim $_{\mathrm{h}, \mathrm{l}, \mathrm{t}}$. Claim $_{\mathrm{h}, \mathrm{l}, \mathrm{t}}$ stands for the amount of all claims to country 1 held by banks in country $h$ at period $t$. As the ECB only publish data twice over the observation period, it is difficult to use the lagged bank exposure. Claim_ $\mathrm{G}_{\mathrm{h}, \mathrm{l}, \mathrm{t}}$ stands for the aggregate amount of public claims to country 1 held by banks in country $h$ at period t. Claim_ $G_{h, l, t}$ stands for the aggregate amount of claims to financial institutions in country 1 held by banks in country $h$ at period t. Claim_ $\mathrm{C}_{\mathrm{h}, \mathrm{l}, \mathrm{t}}$ stands for the aggregate amount of claims to non-financial corporates in country 1 held by banks in country $h$ at period $t$.

\begin{tabular}{|c|c|c|c|}
\hline & $\begin{array}{r}\text { Sovereig } \\
\quad(j=1\end{array}$ & $\begin{array}{r}\text { Bank } \\
(j=2)\end{array}$ & $\begin{array}{r}\text { Corporate } \\
(j=3)\end{array}$ \\
\hline \multirow{3}{*}{$\begin{array}{l}\text { Sovereign } \\
(k=1) \\
\text { Bank }\end{array}$} & $T B_{l, h, t-1}+T B_{h, l, t-1}$ & Claim_G $_{l, h, t}$ & Export $_{l, h, t-1}+$ Export $_{h, l, t-1}$ \\
\hline & $\overline{\sum_{l} T B_{l, h, t}^{*}+\sum_{h} T B_{h . l, t}^{*}}$ & $\overline{\sum_{l} \text { Claim_ } G_{l, h, t}}$ & \multirow{2}{*}{ 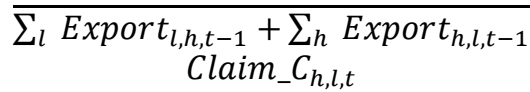 } \\
\hline & Claim_- $_{h, l, t}$ & Claim_ $B_{h, l, t}+$ Claim_ $B_{l, h, t}$ & \\
\hline $\begin{array}{l}\text { Bank } \\
(k=2)\end{array}$ & $\overline{\sum_{h} \text { Claim_ } G_{h, l, t}}$ & $\overline{\sum_{h} \text { Claim_ } B_{h, l, t}+\sum_{l} \text { Claim_ } B_{l,}}$ & \multirow{2}{*}{$\begin{array}{c}\overline{\sum_{h} \text { Claim_ }_{-} C_{h, l, t}} \\
\text { Export }_{l, h, t-1}+\text { Export }_{h, l, t-1}\end{array}$} \\
\hline \multirow{2}{*}{$\begin{array}{l}\text { Corporate } \\
(k=3)\end{array}$} & Export $_{h, l, t}^{*}+$ Export $_{l, h, t}^{*}$ & Claim_ $_{-} C_{l, h, t}$ & \\
\hline & $\sum_{h}$ Export $_{h . l, t}^{*}+\sum_{l}$ Export $_{l, h, t}^{*}$ & $\sum_{l}$ Claim_ $C_{l, h, t}$ & 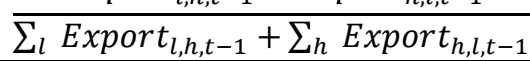 \\
\hline
\end{tabular}

The weight matrix defined as in Table A6-1 is then row-standardized to be the corresponding $W_{t}^{j, k}$, so that for each $h, \sum_{h, t} w_{h, l, t}^{j, k}=1$.

2) DFI and bank

Another linkage that may capture the cross-country dependence is the bilateral FDI. A pair of countries with larger bilateral FDI may be more heavily exposed to counterparty shocks than counties with smaller FDI. If the FDI between two countries increases, the corporate performance 
co-movements can increase due to stronger demand from foreign investors. Therefore, trade flow can be substitute by FDI from the FDI Statistics of the OECD. Dank exposure data are still from BIS.

\section{Table A6-2: Definition of cross-border interconnectedness}

Note: $\mathrm{FDI}_{\mathrm{h}, \mathrm{l}, \mathrm{t}-1}$ stands for the outward FDI from country $\mathrm{h}$ to country 1 in one month before period t. $\mathrm{DB}, \mathrm{h}, \mathrm{l}, \mathrm{t}-1$ stands for the FDI and bank exposures between country 1 and $\mathrm{h}$, where $\mathrm{DB}_{\mathrm{h}, \mathrm{l}, \mathrm{t}-1}=\mathrm{FDI}_{\mathrm{h}, \mathrm{l}, \mathrm{t}-1}+\mathrm{Claim}_{\mathrm{h}, \mathrm{l}, \mathrm{t}-1}$. Claim Cl,l,t-1 stands for the amount of claims to all sectors of country 1 held by banks in country $h$ in period $t-1$.

\begin{tabular}{|c|c|c|c|}
\hline & $(j=$ & $\begin{aligned} \mathbf{B a} \\
(j=\end{aligned}$ & $\begin{array}{r}\text { Corporate } \\
(j=3) \\
\end{array}$ \\
\hline & $+D B_{l, h, t-1}$ & + Claim $_{l, h, t-1}$ & $F D I_{h, l, t-1}+F D I_{l, h, t-1}$ \\
\hline & ${ }_{1}+\sum_{l} D B_{l, h, t-1}$ & $+\sum_{l}$ Claim $_{l, h, t}$ & $\overline{\sum_{h} F D I_{h, l, t-1}+\sum_{l} F D I_{l, h, t-1}}$ \\
\hline $\mathrm{B}$ & $1+$ Claim $_{l, h}$ & $\operatorname{laim}_{l, h, t-1}$ & Claim $_{h, l, t-1}+$ Claim $_{l, h, t-1}$ \\
\hline & ${ }_{1}+\sum_{l}$ Clai & $\overline{\sum_{l} \text { Claim }_{l, h, t-1}}$ & $\overline{\sum_{h} \operatorname{Claim}_{h, l, t-1}+\sum_{l} \text { Claim }_{l, h, t-1}}$ \\
\hline $\begin{array}{l}\text { Corporate } \\
(k=3)\end{array}$ & $\frac{F D I_{h, l, t-1}+F D I_{l, h, t-1}}{\sum_{h} F D I_{h, l, t-1}+\sum_{l} F D I_{l, h, t-1}}$ & $\frac{\text { Claim }_{h, l, t-1}+\text { Claim }_{l, h, t-1}}{\sum_{h} \text { Claim }_{h, t,-1}+\sum_{l} \text { Claim }_{l, t-1}}$ & $\frac{F D I_{h, l, t-1}+F D I_{l, h, t-1}}{\sum_{h} F D I_{h, l, t-1}+\sum_{l} F D I_{l, h, t-1}}$ \\
\hline
\end{tabular}

The weight matrix defined as in Table A6-2 is then row-standardized to be the corresponding $W_{t}^{j, k}$, so that for each $h, \sum_{h, t} w_{h, l, t}^{j, k}=1$.

3) Trade and financial portfolio

Portfolio investment can also capture housing co-movements. If portfolio investment between two countries increases, co-movement can increase due to stronger indirect demand from foreign investors through investment in securities. Therefore, bank claims can be substituted by portfolio investment from the IMF GIPS database.

\section{Table A6-3: Definition of cross-border interconnectedness}

Note: Trade Flow come from the Trade Statistics of the OECD. Data for bank balance-sheet exposure come from BIS aggregate bank exposure data. Export $t_{\mathrm{h}, \mathrm{l}, \mathrm{t}-1}$ stands for the export from country 1 to country $\mathrm{h}$ in one month before period t. $\mathrm{TP}_{\mathrm{h}, \mathrm{l}, \mathrm{t}-1}$ stands for the trade and financial exposure between country 1 and $\mathrm{h}$, where $\mathrm{TP}_{\mathrm{h}, \mathrm{l}, \mathrm{t}-1}=$ Export $_{\mathrm{h}, \mathrm{l}, \mathrm{t}-1}+$ Port $_{\mathrm{h}, \mathrm{l}, \mathrm{t}-1}$. Port $\mathrm{P}_{\mathrm{h}, \mathrm{l}, \mathrm{t}-1}$ stands for the amount of portfolios to all sectors of country 1 held by banks in country $\mathrm{h}$ in period $\mathrm{t}-1$.

\begin{tabular}{|c|c|c|c|}
\hline & $\begin{array}{r}\text { Sovereign } \\
(j=1)\end{array}$ & $\begin{array}{c}\text { Bank } \\
(j=2)\end{array}$ & $\begin{array}{r}\begin{array}{r}\text { Corporate } \\
(j=3)\end{array} \\
\end{array}$ \\
\hline $\begin{array}{l}\text { Sovereign } \\
(k=1)\end{array}$ & $\frac{T P_{h, l, t-1}+T P_{l, h, t-1}}{\sum_{h} T P_{h, l, t-1}+\sum_{l} T P_{l, h, t-1}}$ & $\frac{\text { Port }_{h, l, t-1}+\text { Port }_{l, h, t-1}}{\sum_{h} \text { Port }_{h, l, t-1}+\sum_{l} \text { Port }_{l, h, t-1}}$ & $\frac{\text { Export }_{l, h, t-1}+\text { Export }_{h, l, t-1}}{\sum_{l} \text { Export }_{l, h, t-1}+\sum_{h} \text { Export }_{h, l, t}}$ \\
\hline
\end{tabular}




\begin{tabular}{|c|c|c|c|}
\hline $\begin{array}{l}\text { Bank } \\
(k=2)\end{array}$ & $\frac{\text { Port }_{h, l, t-1}+\operatorname{Port}_{l, h, t-1}}{\sum_{h} \operatorname{Port}_{h, l, t-1}+\sum_{l} \operatorname{Port}_{l, h, t-1}}$ & $\begin{array}{c}\text { Port }_{h, l, t-1}+\operatorname{Port}_{l, h, t-1} \\
\sum_{h} \operatorname{Port}_{h, l, t-1}+\sum_{l} \operatorname{Port}_{l, h, t-1} \\
\operatorname{Port}_{h, l, t-1}+\operatorname{Port}_{l, h, t-1}\end{array}$ & $\frac{\text { Port }_{h, l, t-1}+\operatorname{Port}_{l, h, t-1}}{\sum_{h} \operatorname{Port}_{h, l, t-1}+\sum_{l} \operatorname{Port}_{l, h, t-1}}$ \\
\hline & Export $_{l, h, t-1}+\sum_{h}$ Export $_{t}$ & 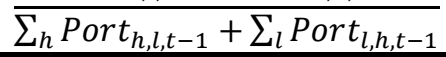 & $\sum_{l}$ Export $_{l, h, t-1}+\sum_{h}$ Export $_{h, l, l}$ \\
\hline
\end{tabular}

The weight matrix defined as in Table A6-3 is then row-standardized to be the corresponding $W_{t}^{j, k}$, so that for each $h, \sum_{h, t} w_{h, l, t}^{j, k}=1$.

\section{4) Openness Similarity}

Instead of the trade or investment linkages, a measure of openness from the Heritage Foundation can be used to account for both trade and investment openness. The average of the trade freedom index and the investment freedom index is used. Trade freedom is defined as 'the absence of tariff and non-tariff barriers that affect imports and exports of goods and services' (The Heritage Foundation, 2014). Investment freedom is determined by the number of restrictions on foreign investment, such as restrictions on real estate purchases, foreign exchange and capital controls, different national treatment of foreign investment, bureaucracy, expropriation of investment, etc.

\section{Table A6-4: Definition of cross-border interconnectedness}

Note: open ${ }_{1}$ is the openness score in country 1 at period $t$.

\begin{tabular}{lrrr}
\hline & $\begin{array}{r}\text { Sovereign } \\
(\mathbf{j}=\mathbf{1})\end{array}$ & $\begin{array}{r}\text { Bank } \\
(\mathbf{j}=\mathbf{2})\end{array}$ & $\begin{array}{r}\text { Corporate } \\
(\boldsymbol{j}=\mathbf{3})\end{array}$ \\
\hline $\begin{array}{l}\text { Sovereign } \\
(k=1)\end{array}$ & open $_{l, t}-$ open $_{h, t} \mid$ & $\mid$ open $_{l, t}-$ open $_{h, t} \mid$ & $\mid$ open $_{l, t}-$ open $_{h, t} \mid$ \\
$\begin{array}{l}\text { Bank } \\
k=2)\end{array}$ & open $_{l, t}-$ open $_{h, t} \mid$ & $\mid$ open $_{l, t}-$ open $_{h, t} \mid$ & $\mid$ open $_{l, t}-$ open $_{h, t} \mid$ \\
$\begin{array}{l}\text { Corporate } \\
(k=3)\end{array}$ & open $_{l, t}-$ open $_{h, t} \mid$ & $\mid$ open $_{l, t}-$ open $_{h, t} \mid$ & $\mid$ open $_{l, t}-$ open $_{h, t} \mid$ \\
\hline
\end{tabular}

The similarity in openness is then converted to continuity matrix $(C)$ by:

$C_{l, h, t}=1-\frac{F_{l, h, t}^{\text {open }}-\min \left(F_{l, h, t}^{\text {open }}\right)}{\max \left(F_{l, h, t}^{\text {open }}\right)-\min \left(F_{l, h, t}^{o p e n}\right)}$, where $F_{l, h, t}^{\text {open }}=\operatorname{open}_{l, t}-$ open $_{h, t} \mid$.

And $C_{l, h}$ is then row-standardized to be the corresponding $W_{t}^{j, k}$, so that for each $h, \sum_{h, t} w_{h, l, t}^{j, k}=$ 
1.

5) Distance

The geographic proximity can, however, also capture stronger trade and investment linkages which may be due to better information and familiarity with the neighbour country.

\section{Table A6-5: Definition of cross-border interconnectedness}

Note: $\mathrm{D}_{1, \mathrm{~h}}$ is the distance between capital city of country 1 and $\mathrm{h}$.

\begin{tabular}{lccc}
\hline & $\begin{array}{r}\text { Sovereign } \\
(\mathbf{j}=\mathbf{1})\end{array}$ & $\begin{array}{r}\text { Bank } \\
(\mathbf{j}=\mathbf{2})\end{array}$ & $\begin{array}{r}\text { Corporate } \\
(\mathbf{j}=\mathbf{3})\end{array}$ \\
\hline $\begin{array}{l}\text { Sovereign } \\
(k=1)\end{array}$ & $D_{l, h}$ & $D_{l, h}$ & $D_{l, h}$ \\
$\begin{array}{l}\text { Bank } \\
(k=2)\end{array}$ & $D_{l, h}$ & $D_{l, h}$ & $D_{l, h}$ \\
$\begin{array}{l}\text { Corporate } \\
(k=3)\end{array}$ & $D_{l, h}$ & $D_{l, h}$ & $D_{l, h}$ \\
\hline
\end{tabular}

The geographic distance is then converted to continuity matrix $(C)$ by:

$C_{l, h}=1-\frac{D_{l, h}-\min \left(D_{l, h}\right)}{\max \left(D_{l, h}\right)-\min \left(D_{l, h}\right)}$,

and $C_{l, h}$ is then row-standardized to be the corresponding $W_{t}^{j, k}$, so that for each $h, \sum_{h, t} w_{h, l, t}^{j, k}=1$. 


\section{Appendix 7: Error variance decomposition of sovereign, banking, and corporate default}

risks: $\mathbf{T}=\mathbf{1 0}$

Note: This table shows the forecast error variance decomposition based on alternative model specification or estimators. The weight matrices are defined as baseline model, as specified in section 2.2. The variance decomposition is based on restricted SpVAR, where insignificant parameters are excluded. The shocks are restricted to strictly exogenous shocks using the structured impulse response function proposed by den Haan, Sumner, \& Yamashiro (2007). The values are the average proportion of the variance of the eleven countries predicted by the respective shocks. The absolute level of variance is reported in round brackets. The $90 \%$ confidence interval based on 200 randomly generated weight matrices is in Panel 2 of Table 4 . When the predicted variance is above the upper bound of the $90 \%$ confidence, the cell is bonded.

\begin{tabular}{|c|c|c|c|c|c|c|}
\hline & $\begin{array}{r}\text { Domestic } \\
\text { Sovereign } \\
\text { Shock } \\
\end{array}$ & $\begin{array}{r}\text { Foreign } \\
\text { Sovereign Shock }\end{array}$ & $\begin{array}{r}\text { Domestic } \\
\text { Banking Shock }\end{array}$ & $\begin{array}{r}\text { Foreign Banking } \\
\text { Shock }\end{array}$ & $\begin{array}{r}\text { Domestic } \\
\text { Corporate Shock }\end{array}$ & $\begin{array}{r}\text { Foreign } \\
\text { Corporate } \\
\text { Shock } \\
\end{array}$ \\
\hline \multicolumn{7}{|c|}{ Model 8: Initial Trade/Bank Exposure } \\
\hline Sovereign CDS & $61 \%$ & $18 \%$ & $3 \%$ & $7 \%$ & $3 \%$ & $5 \%$ \\
\hline change & $(0.0344)$ & $(0.0102)$ & $(0.0016)$ & $(0.0039)$ & $(0.0018)$ & $(0.0025)$ \\
\hline Banking CDS & $2 \%$ & $4 \%$ & $67 \%$ & $24 \%$ & $0 \%$ & $1 \%$ \\
\hline change & $(0.0009)$ & $(0.0013)$ & $(0.0253)$ & $(0.0088)$ & $(0.0001)$ & $(0.0002)$ \\
\hline Corporate CDS & $0 \%$ & $2 \%$ & $4 \%$ & $18 \%$ & $54 \%$ & $19 \%$ \\
\hline change & $(0.0001)$ & $(0.0005)$ & $(0.0012)$ & $(0.0055)$ & $(0.0166)$ & $(0.0055)$ \\
\hline \multicolumn{7}{|c|}{ Model 9: Contemporaneous Trade/Bank Exposure } \\
\hline Sovereign CDS & $58 \%$ & $17 \%$ & $3 \%$ & $8 \%$ & $5 \%$ & $6 \%$ \\
\hline change & $(0.0340)$ & $(0.0096)$ & $(0.0019)$ & $(0.0044)$ & $(0.0027)$ & $(0.0037)$ \\
\hline Banking CDS & $4 \%$ & $5 \%$ & $65 \%$ & $19 \%$ & $2 \%$ & $2 \%$ \\
\hline change & $(0.0014)$ & $(0.0018)$ & $(0.0233)$ & $(0.0067)$ & $(0.0005)$ & $(0.0006)$ \\
\hline Corporate CDS & $1 \%$ & $3 \%$ & $4 \%$ & $20 \%$ & $54 \%$ & $16 \%$ \\
\hline change & $(0.0002)$ & $(0.0009)$ & $(0.0012)$ & $(0.0056)$ & $(0.0156)$ & $(0.0045)$ \\
\hline \multicolumn{7}{|c|}{ Model 10: Including Country-Specific GDP and Credit } \\
\hline Sovereign & $60 \%$ & $13 \%$ & $5 \%$ & $11 \%$ & $4 \%$ & $5 \%$ \\
\hline $\mathrm{CDS}$ & $(0.0307)$ & $(0.0066)$ & $(0.0027)$ & $(\mathbf{0 . 0 0 5 5 )}$ & $(0.0019)$ & $(0.0024)$ \\
\hline change & {$[0.0298 ; 0.0365]$} & {$[0.0032 ; 0.0082]$} & {$[0.0002 ; 0.0011]$} & {$[0.0003 ; 0.0022]$} & {$[0.0004 ; 0.0021]$} & {$[0.0004 ; 0.0039]$} \\
\hline Banking & $2 \%$ & $2 \%$ & $71 \%$ & $21 \%$ & $0 \%$ & $1 \%$ \\
\hline CDS & $(0.0006)$ & $(0.0008)$ & $(0.0242)$ & $(0.0071)$ & $(0.0001)$ & $(0.0002)$ \\
\hline change & {$[0.0005 ; 0.0010]$} & {$[0.0004 ; 0.0017]$} & {$[0.0200 ; 0.0239]$} & {$[0.0012 ; 0.0040]$} & {$[0.0000 ; 0.0010]$} & {$[0.0001 ; 0.0023]$} \\
\hline Corporate & $0 \%$ & $1 \%$ & $5 \%$ & $22 \%$ & $54 \%$ & $14 \%$ \\
\hline CDS & $(0.0001)$ & $(0.0004)$ & $(0.0014)$ & $(0.0061)$ & $(0.0152)$ & $(0.0039)$ \\
\hline change & {$[0.0001 ; 0.0010]$} & {$[0.0001 ; 0.0019]$} & {$[0.0001 ; 0.0009]$} & {$[0.0001 ; 0.0018]$} & {$[0.0145 ; 0.0182]$} & {$[0.0017 ; 0.0043]$} \\
\hline \multicolumn{7}{|c|}{ Model 11: Inconstant Covariance Matrix } \\
\hline Sovereign & $60 \%$ & $20 \%$ & $3 \%$ & $6 \%$ & $3 \%$ & $5 \%$ \\
\hline CDS & $(0.0367)$ & $(0.0121)$ & $(0.0017)$ & $(0.0037)$ & $(0.0020)$ & $(0.0029)$ \\
\hline change & {$[0.0327 ; 0.0424]$} & {$[0.0038 ; 0.0088]$} & {$[0.0008 ; 0.0022]$} & {$[0.0004 ; 0.0026]$} & {$[0.0007 ; 0.0044]$} & {$[0.0005 ; 0.0032]$} \\
\hline Banking & $4 \%$ & $6 \%$ & $66 \%$ & $19 \%$ & $1 \%$ & $1 \%$ \\
\hline $\mathrm{CDS}$ & $(0.0016)$ & $(0.0022)$ & $(0.0239)$ & $(0.0067)$ & $(0.0002)$ & $(0.0005)$ \\
\hline change & {$[0.0012 ; 0.0034]$} & {$[0.0003 ; 0.0028]$} & {$[0.0211 ; 0.0249]$} & {$[0.0011 ; 0.0052]$} & {$[0.0006 ; 0.0026]$} & {$[0.0001 ; 0.0022]$} \\
\hline Corporate & $3 \%$ & $7 \%$ & $4 \%$ & $16 \%$ & $52 \%$ & $15 \%$ \\
\hline CDS & $(0.0010)$ & $(0.0021)$ & $(0.0011)$ & $(0.0046)$ & $(0.0155)$ & $(0.0042)$ \\
\hline change & {$[0.0002 ; 0.0026]$} & {$[0.0003 ; 0.0032]$} & {$[0.0005 ; 0.0022]$} & {$[0.0002 ; 0.0015]$} & {$[0.0149 ; 0.0203]$} & {$[0.0020 ; 0.0052]$} \\
\hline
\end{tabular}




\section{Appendix 8: Alternative estimates}

Table A7: Estimation results of SpVAR model with OLS and IV estimates

Notes: Estimation is for the 2008M1-2013M12 period based on Equation (1). G stands for logdifferenced sovereign CDS spreads. B stands for log-differenced banking CDS spreads. C stands for logdifferenced corporate CDS spreads. $\rho$ is the contemporaneous spatial coefficient, $\mathrm{W}$ is defined on the basis of bilateral trade and/or bank exposure, as in section 2.2. $\phi$ stands for the lagged autoregressive coefficients and $\gamma$ is the autoregressive coefficient. Standard Error is reported in brackets. ${ }^{* * *}$ means that the null can be rejected at the $1 \%$ level.

\begin{tabular}{|c|c|c|c|c|c|c|}
\hline \multirow[b]{2}{*}{ Model 1} & \multicolumn{3}{|r|}{ OLS } & \multicolumn{3}{|r|}{ IV } \\
\hline & $\begin{array}{r}\mathbf{G} \\
(j=1)\end{array}$ & $\begin{array}{r}\text { B } \\
(j=2) \\
\end{array}$ & $\begin{array}{r}\begin{array}{r}C \\
(j=3)\end{array} \\
\end{array}$ & $\begin{array}{r}\mathbf{G} \\
(j=1)\end{array}$ & $\begin{array}{r}\text { B } \\
(j=2)\end{array}$ & $\begin{array}{r}C \\
(j=3) \\
\end{array}$ \\
\hline$\rho$ & & & & & & \\
\hline $\mathrm{W}^{*} \mathrm{G}$ & $\begin{array}{r}0.687 * * * \\
(0.044)\end{array}$ & $\begin{array}{l}-0.047 \\
(0.043)\end{array}$ & $\begin{array}{r}-0.059 * \\
(0.034)\end{array}$ & $\begin{array}{r}0.692 * * * \\
(0.044)\end{array}$ & $\begin{array}{r}0.014 \\
(0.040)\end{array}$ & $\begin{array}{l}-0.014 \\
(0.032)\end{array}$ \\
\hline $\mathrm{W} * \mathrm{~B}$ & $\begin{array}{l}-0.081 \\
(0.064)\end{array}$ & $\begin{array}{r}0.649 * * * \\
(0.048)\end{array}$ & $\begin{array}{r}0.098 * * \\
(0.046)\end{array}$ & $\begin{array}{l}-0.079 \\
(0.065)\end{array}$ & $\begin{array}{r}0.649 * * * \\
(0.051)\end{array}$ & $\begin{array}{r}0.111 * * * \\
(0.044)\end{array}$ \\
\hline $\mathrm{W}^{*} \mathrm{C}$ & $\begin{array}{l}-0.075 \\
(0.093)\end{array}$ & $\begin{array}{l}-0.031 \\
(0.076)\end{array}$ & $\begin{array}{r}0.784 * * * \\
(0.057)\end{array}$ & $\begin{array}{l}-0.083 \\
(0.094)\end{array}$ & $\begin{array}{r}0.095 \\
(0.072)\end{array}$ & $\begin{array}{r}0.835^{* * *} \\
(0.058)\end{array}$ \\
\hline$\gamma$ & & & & & & \\
\hline G_0 & - & $\begin{array}{r}0.124 * * * \\
(0.030)\end{array}$ & $\begin{array}{r}0.104 * * * \\
(0.025)\end{array}$ & - & $\begin{array}{r}0.078 * * \\
(0.040)\end{array}$ & $\begin{array}{r}0.064^{* *} \\
(0.031)\end{array}$ \\
\hline B_0 & $\begin{array}{r}0.180 * * * \\
(0.044)\end{array}$ & 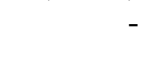 & $\begin{array}{r}0.070 * * * \\
(0.030)\end{array}$ & $\begin{array}{r}0.175 * * * \\
(0.045)\end{array}$ & - & $\begin{array}{r}0.055 \\
(0.042)\end{array}$ \\
\hline C_0 & $\begin{array}{r}0.224 * * * \\
(0.054)\end{array}$ & $\begin{array}{r}0.128^{* * *} \\
(0.044)\end{array}$ & - & $\begin{array}{r}0.232 * * * \\
(0.055)\end{array}$ & $\begin{array}{r}0.046 \\
(0.059)\end{array}$ & - \\
\hline$\varphi$ & & & & & & \\
\hline G_0 & $\begin{array}{l}-0.001 \\
(0.032)\end{array}$ & $\begin{array}{r}0.072 * * * \\
(0.026)\end{array}$ & $\begin{array}{r}0.013 \\
(0.021)\end{array}$ & $\begin{array}{l}-0.000 \\
(0.032)\end{array}$ & $\begin{array}{r}0.074 * * * \\
(0.027)\end{array}$ & $\begin{array}{r}0.015 \\
(0.022)\end{array}$ \\
\hline B_0 & $\begin{array}{r}0.002 \\
(0.037)\end{array}$ & $\begin{array}{r}0.027 \\
(0.031)\end{array}$ & $\begin{array}{r}0.006 \\
(0.025)\end{array}$ & $\begin{array}{r}0.002 \\
(0.037)\end{array}$ & $\begin{array}{r}0.031 \\
(0.031)\end{array}$ & $\begin{array}{r}0.008 \\
(0.025)\end{array}$ \\
\hline C_ 0 & 0.055 & -0.038 & $-0.059 * *$ & 0.055 & -0.041 & -0.059 \\
\hline $\begin{array}{l}\text { Control } \\
\text { Variables }\end{array}$ & Yes & Yes & Yes & Yes & Yes & Yes \\
\hline $\begin{array}{l}\text { Country- } \\
\text { Specific } \\
\text { Intercept }\end{array}$ & Yes & Yes & Yes & Yes & Yes & Yes \\
\hline $\bar{R}^{2}$ & 0.5210 & 0.4814 & 0.5911 & 0.5229 & 0.4670 & 0.5825 \\
\hline
\end{tabular}

